\title{
Satellite- and ground-based CO total column observations over 2010 Russian fires: accuracy of top-down estimates based on thermal IR satellite data
}

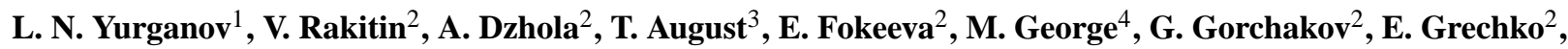 \\ S. Hannon ${ }^{1}$, A. Karpov ${ }^{2}$, L. Ott ${ }^{5}$, E. Semutnikova ${ }^{6}$, R. Shumsky ${ }^{2}$, and L. Strow ${ }^{1}$ \\ ${ }^{1}$ Joint Center for Earth Systems Technology, University of Maryland Baltimore County, Baltimore, MD, USA \\ ${ }^{2}$ Obukhov Institute of Atmospheric Physics, Moscow, Russia \\ ${ }^{3}$ EUMETSAT, Darmstadt, Germany \\ ${ }^{4}$ UPMC, Univ. Paris 06, Univ. Versailles St-Quentin, CNRS/INSU, LATMOS-IPSL, Paris, France \\ ${ }^{5}$ NASA, Goddard Space Flight Center, Greenbelt, MD, USA \\ ${ }^{6}$ Mosecomonitoring, Moscow, Russia
}

Received: 18 March 2011 - Published in Atmos. Chem. Phys. Discuss.: 19 April 2011

Revised: 22 July 2011 - Accepted: 1 August 2011 - Published: 4 August 2011

\begin{abstract}
CO total column data are presented from three space sounders and two ground-based spectrometers in Moscow and its suburbs during the forest and peat fires that occurred in Central Russia in July-August 2010. Also presented are ground-based in situ $\mathrm{CO}$ measurements. The Moscow area was strongly impacted by the $\mathrm{CO}$ plume from these fires. Concurrent satellite- and ground-based observations were used to quantify the errors of $\mathrm{CO}$ top-down emission estimates. On certain days, $\mathrm{CO}$ total columns retrieved from the data of the space-based sounders were 2-3 times less than those obtained from the ground-based sun-tracking spectrometers. The depth of the polluted layer over Moscow was estimated using total column measurements compared with $\mathrm{CO}$ volume mixing ratios in the surface layer and on the TV tower and found to be around $360 \mathrm{~m}$. The missing CO that is the average difference between the CO total column accurately determined by the ground spectrometers and that retrieved by AIRS, MOPITT, and IASI was determined for the Moscow area between 1.6 and $3.3 \times 10^{18}$ molec $\mathrm{cm}^{-2}$. These values were extrapolated onto the entire plume; subsequently, the $\mathrm{CO}$ burden (total mass) over Russia during the fire event was corrected. A top-down estimate of the total emitted CO, obtained by a simple mass balance model increased by $40-100 \%$ for different sensors due to this correction. Final assessments of total $\mathrm{CO}$ emitted by Russian wildfires obtained from different sounders are between 34 and $40 \mathrm{Tg}$ CO during July-August 2010.
\end{abstract}

Correspondence to: L. N. Yurganov (yurganov@umbc.edu)

\section{Introduction}

Carbon monoxide (CO) is recognized as a useful tracer of biomass burning and anthropogenic pollution (Logan et al., 1981; Edwards et al., 2004, 2006; McMillan et al., 2010). CO total source is estimated by Holloway et al. (2000) as $2491 \mathrm{Tg} \mathrm{yr}^{-1}$ for the 1990's and by Duncan et al. (2007) in the range between 2236 and $2489 \mathrm{Tg} \mathrm{yr}^{-1}$ depending on biomass burning emissions. Duncan et al. (2007) found a $2 \%$ per year downward trend from 1988 to 1997. They explained this trend by a decrease in European emissions. Contributions from wildfires were counted using the GFED3 model by van der Werf et al. (2010), and vary from year to year, both globally and regionally. From 2000 to 2009, global fire emissions varied between 253 (2001) and 388 (2006) $\mathrm{Tg} \mathrm{yr}^{-1}$, i.e. between $11 \%$ and $16 \%$ of total source. Uncertainties in these bottom-up calculations are connected with estimates of burned areas, fuel loads, emission factors, etc. As a way to carry out top-down estimates of $\mathrm{CO}$ fire emissions, satellite measurements of $\mathrm{CO}$ are of great importance.

CO has been measured from space since 1981 (Reichle et al., 1986). Those pioneering observations revealed biomass burning, especially over Africa, as the most prominent global $\mathrm{CO}$ feature and confirmed the North-South CO total column (TC) gradient discovered earlier using a ship-based spectrometer (Malkov et al., 1976). CO is now measured operationally by several satellite-borne sounders, and the results of most retrievals are available on the Web. CO has very distinct spectral features; the fundamental band and its first overtone, which are located in the Thermal Infrared Red

Published by Copernicus Publications on behalf of the European Geosciences Union. 
(TIR) and Near Infrared Red (NIR) spectral regions, respectively. Most of the data come from the TIR region (MAPS, MOPITT, AIRS, TES, IASI ) near $4.6 \mu \mathrm{m}$. For nadir sounding of tropospheric composition, a principal limitation of TIR instruments is their low sensitivity below $2-3 \mathrm{~km}$ of altitude, mostly in the boundary layer (BL). As a result, CO TC corresponding the retrieved $\mathrm{CO}$ profile (in what follows, the retrieved CO TC for brevity) is different from the actual TC; the equation connecting them includes a sensitivity function (averaging kernel), the true profile, and a priori profile; consequently, the real TC cannot be derived from the retrieved one without knowing the true $\mathrm{CO}$ profile. However, in absence of strong surface emissions (e.g. wildfires), true $\mathrm{CO}$ profiles are close to the a priori profiles and the total error of CO TC retrieval is generally less than $\pm 10 \%$ (Barret et al., 2003; Clerbaux et al., 2008, 2009; Emmons et al., 2004, 2007, 2009; Warner et al., 2007; McMillan et al., 2008, 2010; Yurganov et al., 2008, 2010). This accuracy is high enough for the background CO, because its TC in the global unpolluted troposphere vary between $1 \times 10^{18} \mathrm{molec} \mathrm{cm}^{-2}$ in the Southern Hemisphere during the austral summer and $2.5 \times 10^{18} \mathrm{molec}^{-2}$ in the $\mathrm{NH}$ during the boreal winter (Yurganov et al., 2010).

MOPITT TIR and AIRS data have been used for quantification of $\mathrm{CO}$ sources using top-down inverse global modeling (Pfister et al., 2005; Turquety et al., 2008; Chevallier et al., 2009; Kopacz et al, 2010; Fisher et al., 2010). CO mixing ratios retrieved from AIRS spectra have been used to investigate biomass burning and anthropogenic pollution (McMillan et al., 2005, 2008, 2010; Warner et al., 2007). Unfortunately, inadequate sensitivity to the BL is still a problem for top-down estimates of emission rates, especially for wildfires.

In the NIR, the reflected solar radiation prevails over terrestrial emission and the averaging kernel is less dependent on altitude than that for TIR (de Laat et al., 2007, 2010). The space-based NIR spectrometer SCIAMACHY, sensitive to the $2.3 \mu \mathrm{m}$ first overtone band of $\mathrm{CO}$, encountered problems connected with the gradual deterioration of spectral channels, low signal to noise ratio, aerosol dependence, etc. (Glaudemans et al., 2008; de Laat et al., 2010); to date, the usefulness of SCIAMACHY data, as well of similar data of NIR channel of MOPITT (Deeter et al., 2009), for scientific needs is questionable. In particular, differences between TIR MOPITT V4 and NIR SCIAMACHY (in other words, "missing CO") over biomass burning areas never exceeded $0.5 \times 10^{18}$ molec cm $^{-2}$ (de Laat et al., 2010; Liu et al., 2011) in contradiction to the results of this paper. Moreover, in many cases data of SCIAMACHY over polluted areas were lower than that of MOPITT TIR, a feature explained by cloud effects (Liu et al., 2011). A combination of TIR and NIR data that is planned to be realized in the version 5 of MOPITT (Worden et al., 2010) is a promising approach, but qualitative results (for wildfires, in particular) need to be validated.
This paper presents data from three space sounders and two ground-based spectrometers in Moscow and its suburbs during wildfires that occurred in Central Russia in JulyAugust 2010. The Moscow area was strongly impacted by $\mathrm{CO}$ plume from the peat and forest fires, which occurred to the east and south-east of the city (Konovalov et al., 2011; Witte et al., 2011). On certain days the CO effective TC retrieved from data of space-based sounders was 2-3 times less than those obtained from the ground. With the aid of concurrent measurements of $\mathrm{CO}$ volume mixing ratio (VMR) in the surface layer and on the TV tower the depth of polluted layer over Moscow was estimated $\sim 360 \mathrm{~m}$. The Missing CO (MCO) that is the average difference between the CO TC determined from the ground and that retrieved by IASI, MOPITT, and AIRS was estimated for the Moscow area in the range between $1.6 \times 10^{18}$ and $3.3 \times 10^{18}$ molec cm$^{-2}$; these values were extrapolated onto the entire plume.

This missing CO burden (total mass over the domain under investigation) was added to the retrieved burden. The corrected burden was used as input for a simple mass balance box model to estimate the $\mathrm{CO}$ emission rate during fires. The influence of this correction on the total emitted $\mathrm{CO}$ was estimated between $40 \%$ and $100 \%$, depending on the sensor. The total CO emitted by Russian fires was finally estimated between $34 \mathrm{Tg}$ (AIRS) and $40 \mathrm{Tg}$ (MOPITT) with uncertainty $\sim 30 \%$.

\section{Instruments, retrieval techniques, validation}

\subsection{Satellite data sets}

A part of the Terra platform launched in December 1999, the satellite-borne MOPITT instrument is a TIR/NIR nadirviewing gas correlation radiometer described in detail by Drummond (1992). MOPITT uses a cross-track scan with a swath of $700 \mathrm{~km}$, which allows for almost complete coverage of the Earth's surface in about 3 days, with individual pixels of $22 \mathrm{~km} \times 22 \mathrm{~km}$ horizontal resolution. The sensitivity of the instrument significantly decreases in the BL (Deeter et al., 2004); therefore, the retrieved TC depends on an a priori profile, especially for highly polluted BL. Version 3 (V3), which is now outdated, used a global uniform a priori. MOPITT V4 data set (Deeter et al., 2010) uses climatologically variable a priori (e.g. dots in Fig. 6).

Yurganov et al. (2010) compared MOPITT V3 with TC measured by 7 ground-based spectrometers and found an instrumental/retrieval drift of $1.4-1.8 \%$ per year. This trend was removed in the MOPITT V4 data; a good consistency with aircraft profiles (Emmons et al., 2009) and ground spectrometers (Yurganov et al., 2010) was found; bias in all cases was well inside the limits of $\pm 10 \%$, and no instrumental drift was observed after 2002. MOPITT V4 day time data used in this paper are downloaded from ftp://anonymous@14ft101. larc.nasa.gov/MOPITT. 
Launched onboard NASA's Aqua satellite on 4 May 2002, the AIRS cross-track scanning grating spectrometer provides vertical profiles of the atmosphere with a nadir $45 \mathrm{~km}$ fieldof-regard across a $1650 \mathrm{~km}$ swath (Aumann et al., 2003; Chahine et al., 2006). Although primarily designed as a prototype next-generation temperature and water vapor sounder, the broad spectral coverage of AIRS (3.7 to $16 \mu \mathrm{m}$ with 2378 channels) includes spectral features of $\mathrm{O}_{3}, \mathrm{CO}_{2}, \mathrm{CH}_{4}$, and CO (Haskins and Kaplan, 1992). With such a broad swath, AIRS infrared spectra and cloud-clearing (Susskind et al., 2003) enable day/night retrievals over nearly $70 \%$ of the planet every day $\left(100 \%\right.$ daily coverage between $45^{\circ}$ and $80^{\circ}$ latitude in both hemispheres), with substantial portions of the globe observed twice per day (ascending and descending orbits). Thus, AIRS readily observes global scale transport from large biomass burning sources (McMillan et al., 2005).

AIRS' operational V5 algorithm applies a perturbation function with trapezoidal shapes to retrieve a set of the geophysical states. An eigenvector decomposition technique is employed to a set of modified Jacobian to solve for the geophysical state, and a damping process is used to stabilize the solution (Susskind et al., 2003). The selection of the number and levels of the trapezoidal functions, the magnitude of the damping constraint, and the choice of the first guess profile all affect the performance of the retrieval (Warner et al., 2007; McMillan et al., 2008). CO retrievals are obtained from the $2160-2200 \mathrm{~cm}^{-1}$ portion of the spectrum on the edge of the fundamental vibration-rotation band of $\mathrm{CO}$ (McMillan et al., 2005). A subset of 36 out of 52 spectral channels in the $\mathrm{CO}$ region was selected for the operational retrievals using principle component analysis. The parameters used in the retrievals for this study are described by the AIRS Version 5.0 Released Files Description (http://disc.sci.gsfc. nasa.gov/AIRS/documentation), also published by McMillan et al. (2011).

The AIRS mixing ratios for the $500 \mathrm{mb}$ level between 15 June and 14 August 2004 were validated by Warner et al. (2007). The satellite data agree with airborne measurements to within an average of 10-15 ppbv. AIRS CO TC was validated by Yurganov et al. $(2008,2010)$ by the data of NDAC between 2002 and 2007; in the NH AIRS data were generally $3-5 \%$ percent underestimated. The largest error, however, was observed in the SH during the austral summer: AIRS overestimates TC by $15-20 \%$. The AIRS day time L3 retrievals, version 5, are downloaded from http: //disc.gsfc.nasa.gov/AIRS/index.shtml. Day time data were used for all other sounders as well.

IASI is a Fourier Transform Spectrometer deployed at the EUMETSAT platform Metop-A that measures calibrated spectra of IR radiation emitted from the Earth. IASI has 8461 spectral channels between $645.00 \mathrm{~cm}^{-1}$ and $2760.00 \mathrm{~cm}^{-1}(15.5 \mu \mathrm{m}$ and $3.63 \mu \mathrm{m})$, with a spectral resolution of $0.5 \mathrm{~cm}^{-1}$ after apodisation. The spectral sampling step is $0.25 \mathrm{~cm}^{-1}$. IASI scans the track inside the range of $\pm 48.3^{\circ}$. The instantaneous field of view has a ground resolution of $12 \mathrm{~km}$ at nadir. A more detailed description of the instrument can be found in (Hébert et al., 2004). IASI products are available on-line in the Earth Observation portal: http://www.eumetsat.int/Home/ Main/DataAccess/EOPortal/index.htm?l=en.

The retrieval of CO TC for the IASI spectra was performed using three different algorithms. First, IASI CO distributions were retrieved from IASI radiance spectra (2143$2181 \mathrm{~cm}^{-1}$ spectral range) using the FORLI-CO (Fast Optimal Retrievals on Layers for IASI-CO) retrieval algorithm (Turquety et al., 2009; George et al., 2009; Pommier et al., 2010). The algorithm is based on the Optimal Estimation method (OE) described by Rodgers (2000). The Level 2 operational temperature and water vapor profiles distributed by EUMETSAT (Schlüssel et al., 2005) are used as inputs of the code as well as surface emissivity. These are taken from the monthly climatologies established by Zhou et al. (2011) wherever available, or from the MODIS/TERRA climatology (Wan, 2008). The FORLI-CO algorithm provides CO total columns and profiles on 19 equidistant layers with a step of $1 \mathrm{~km}$, as well as error characterization diagnostics, including an a posteriori error variance-covariance matrix and an averaging kernels AKP for profiles and AKTN for TC. The current version "20100815" uses a global uniform a priori with TC around $1.5 \times 10^{18}$ molec $\mathrm{cm}^{-2}$. Data were filtered when the cloud contamination exceed $25 \%$ of the surface of the IASI pixel. Level 2 IASI FORLI-CO TC data can be downloaded from http://ether.ipsl.jussieu.fr/.

The second one, the Spectral Fitting Algorithm (SFA), is a modification of algorithm for AIRS $\mathrm{CO}_{2}$ (Strow et al., 2008). It uses a radiative transfer model called SARTA, which was originally developed for AIRS as a forward model (Strow et al., 2003). ECMWF analysis/forecast model data are used for temperature, water vapor, and pressure profiles. The algorithm for selecting clear fields of view (Strow et al., 2006) is based on a uniformity filter and several spectral tests. This filter returns only about $1 \%$ of all ocean observations and even less pixels over continent. Moreover, it can not distinguish between clouds and homogeneous surfaces like deserts, or snow covered areas; these areas are missing in the data set.

The retrieval procedure is as follows. Surface skin temperature was adjusted iteratively using 18 IASI window channels between 957 and $964 \mathrm{~cm}^{-1}$. A priori profiles of gases (first guess profiles) were taken from MOPITT V3 algorithm (CO) and ECMWF $\left(\mathrm{H}_{2} \mathrm{O}\right)$. The scaling factors for profiles of gases were retrieved iteratively using $15(\mathrm{CO})$ and $9\left(\mathrm{H}_{2} \mathrm{O}\right)$ channels in the $2147-2169 \mathrm{~cm}^{-1}$ spectral range. To do this, the partial derivatives of radiance $\partial R / \partial \mathrm{SF}$ in the IASI channels that correspond to the lines of $\mathrm{H}_{2} \mathrm{O}$ and $\mathrm{CO}$ were calculated using SARTA, and finally, SF for each iteration and each gas were calculated as $\mathrm{SF}=\left(R_{\text {calc }}-R_{\mathrm{obs}}\right) /(\partial R / \partial \mathrm{SF})$.

This procedure is repeated 4 times. As a result, radiances in the gas-sensitive channels are fitted by the calculated spectrum with some retrieved SF, but radiances between lines 
(windows) are not due to the aerosol extinction/emission. Aerosol dominates in the windows, but the SARTA is designed for the aerosol-free atmosphere. Meanwhile, actual radiances in the window channels are perturbed by aerosol, and its impact may be as large as a few percent $\left(R_{\text {obs }}<\right.$ $R_{\text {calc }}$ ) compared to the aerosol-free case. The SF retrieved for the gases turns out to be overestimated by several percent. To take into account this effect, the calculated radiances for gas-sensitive channels, fitted previously, are divided by $R_{\text {calc }}$ (window) $/ R_{\text {obs }}$ (window), and the iterative fitting for gas-sensitive channels is performed again. Finally, both lines and windows are fitted, and the aerosol error of the retrieved SF is minimized. Comparisons of CO total columns between IASI and ground-based spectrometer show a good agreement and a low scatter (see below).

The third retrieval is based on an artificial neural network (IASI-ANN). This was trained with a collection of synthetic IASI spectra computed with RTIASI-5 for the forward model and a wide range of atmospheric state vectors. The temperature and water vapor profiles were sampled in the ECMWF climatological dataset, while the a priori trace gas profiles were extracted from some runs of the model MOZART. The inputs of this retrieval are a sub-selection of IASI channels, the surface temperature and a coarse temperature profile, the surface pressure and the satellite zenith angle. The theoretical error with the training base is approximately $10 \%$. As a result of global intercomparisons carried out with MOPITT V3 total columns, the typical departures between the two products were found to be between 10 and $15 \%$ (std) and 0 to $15 \%$ (bias), varying with the latitude. The global correlation was as high as 0.8 on average. One advantage of such techniques in comparison to line-fitting methods is a much shorter computation time. The data for June-August 2010 are are published in this paper. The temperature and water vapor profiles were sampled in the ECMWF climatological dataset (Chevallier, 2001), while the a priori trace gas profiles were extracted from some runs of the model MOZART.

\subsection{Retrieval algorithm for ground-based spectrometers; locations of observational sites}

Two ground sites were equipped with almost identical grating spectrometers. One was deployed on the upper floor of the Institute of Atmospheric Physics (IAP), Russian Academy of Sciences, in downtown Moscow $\left(55.74^{\circ} \mathrm{N}\right.$, $37.62^{\circ} \mathrm{E}, 200 \mathrm{~m}$ above sea level (a.s.l.)). Another was at the Zvenigorod Research Station (Yurganov et al., 2002) managed by the IAP, located $53 \mathrm{~km}$ to the west of the first one $\left(55.70^{\circ} \mathrm{N}, 36.78^{\circ} \mathrm{E}, 198 \mathrm{~m}\right.$ a.s.1.). Sun-tracking Ebert-Fastie grating spectrometers with $855 \mathrm{~mm}$ focal length and a grating of 300 grooves $\mathrm{mm}^{-1}$ were employed for measuring absorption spectra of the atmosphere. These instruments, designed and constructed at the IAP (Dianov-Klokov, 1984), have a resolution of approximately $0.2 \mathrm{~cm}^{-1}$ in the 2152 $2160 \mathrm{~cm}^{-1}$ spectral region, with a signal-to-noise ratio better than 100, and are equipped with thermoelectrically cooled PbSe detectors. The retrieval SFA code is written in MATLAB by McKernan et al. (1999) and uses standard non-linear least squares procedures provided by MATLAB. Normally, a standard first guess (a priori) profile of $\mathrm{CO}$ concentration was the same as that used in MOPITT V3, AIRS V5, and IASI-SFA retrievals: $120 \mathrm{ppb}$ near the surface and decreasing mixing ratio with height down to $80 \mathrm{ppb}$ just below the tropopause, corresponding TC is around $2.2 \mathrm{molec} \mathrm{cm}^{-2}$. It was iteratively scaled to minimize the residual between measured and calculated spectra. Insufficient spectral resolution, precision of spectral calibration, as well as instability in the instrumental function, do not allow for retrieval of $\mathrm{CO}$ profiles using this instrument. The CO TC amount is measured with typical estimated uncertainty for an individual measurement of $\pm 7-8 \%$ (Yurganov et al., 2002). Yurganov et al. (2008) examined a dependency of TC on the a priori $\mathrm{CO}$ profile and found a $17 \%$ less $\mathrm{CO}$ TC for a priori with $\mathrm{VMR}=4 \mathrm{ppm}$ near the surface. In other words, a 30fold change in the a priori BL surface VMR resulted in just a $17 \%$ change in the retrieved TC. This low sensitivity to the shape of a priori profile near the surface is a consequence of high sensitivity of the sun-tracking spectrometer to the lower troposphere (see also Sect. 3.2.1 below).

Rakitin et al. (2011) analyzed CO data for these two sites between 1986 and 2005. They found that CO TC over Zvenigorod was perturbed by urban $\mathrm{CO}$ sources just in $3 \%$ of total number of days. Also, for $97 \%$ of days urban parts of CO TC daily means over Moscow were in the range between 0 and $20 \%$ of the rural TC in the same day. Record high CO TC over Moscow, up to $8 \times 10^{18} \mathrm{molec}^{-2}$, were observed only in winter time, never in summer time (excluding wildfire periods). The anthropogenic part of the CO TC has not increased during $19 \mathrm{yr}$ in spite of more than quintuple increase of the motor vehicles number in Moscow. This can be explained by: (1) improvements in automobile engines and reduction of $\mathrm{CO}$ emission, (2) a dramatic decline of industrial activity in Moscow after 1991.

Identical Non-Dispersive IR (NDIR) Thermo Electron 48i-TLE analyzers for local mixing ratio measurements were deployed in Moscow and Zvenigorod. Both have detection limit $0.04 \mathrm{ppm}, 30$-s averaging time, linearity $\pm 1 \%$ full scale, response time $60 \mathrm{~s}$, zero noise $0.02 \mathrm{ppm}$, drift of zero level $(24 \mathrm{~h})$ : $<0.1 \mathrm{ppm}$. One of the Moscow instruments is located at the Meteorological Station of the Moscow State University (MSU, $55.71^{\circ} \mathrm{N}, 37.52^{\circ} \mathrm{E}, 212 \mathrm{~m}$ a.s.1.). CO VMR measurements at the Moscow Ostankino TV tower are performed at three levels above the ground: $2 \mathrm{~m}, 130 \mathrm{~m}$, and $248 \mathrm{~m}$ by the Mosecomonitoring, as a part of the city pollution control network. In Zvenigorod, both the spectrometer and NDIR analyzer are installed side-by-side at the Zvenigorod Research Station. Locations of ground-based instruments are denoted on the map (Fig. 1). 


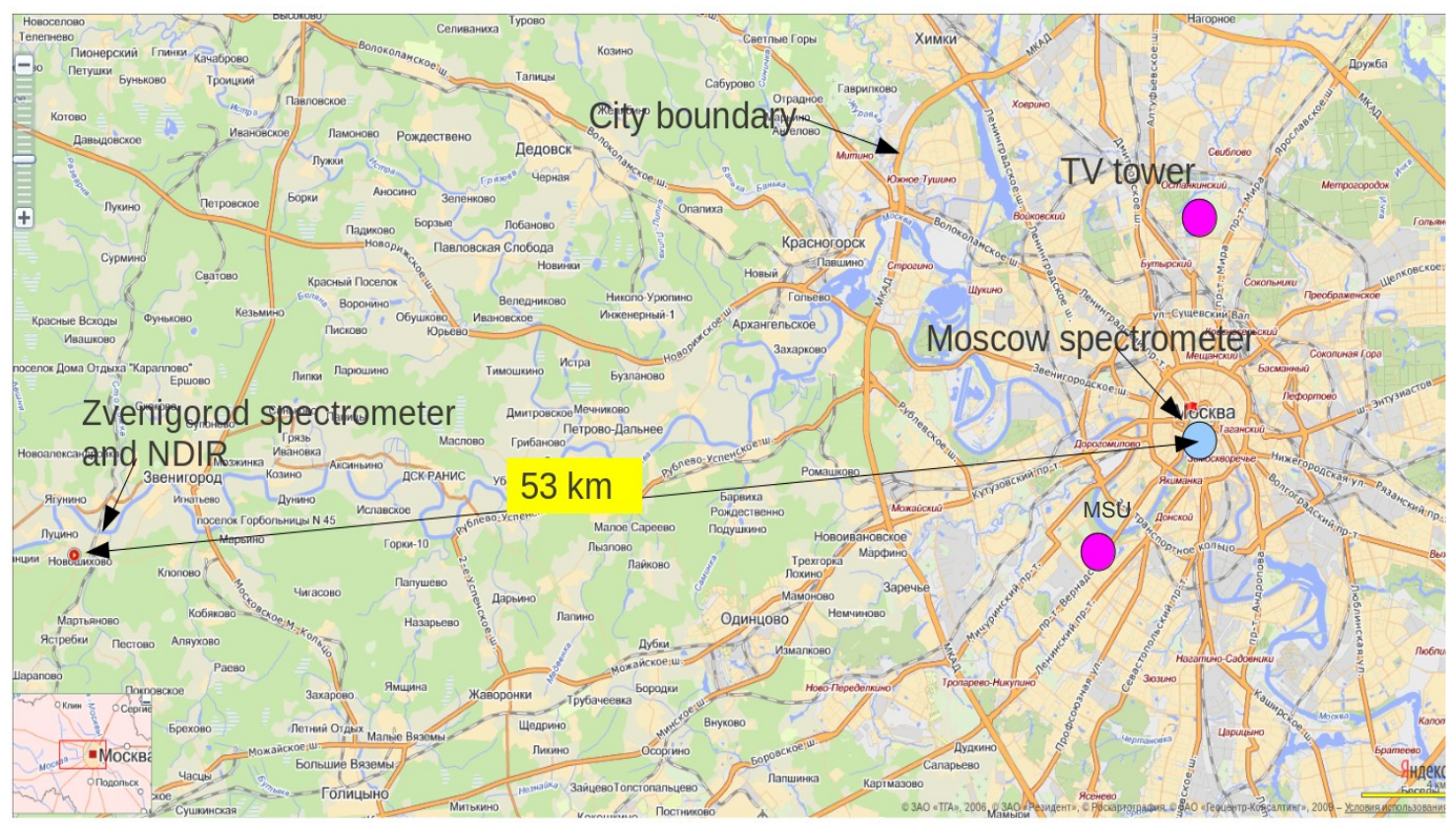

Fig. 1. Moscow, Russia, locations of ground-based instruments.

\subsection{Vertical sensitivity functions}

For MOPITT, AIRS, and IASI-OE retrieval techniques, CO vertical VMR distribution (profile) is retrieved first, TC is derived as integrated profile. Two averaging kernels characterize these two products: AKP for profile and $\boldsymbol{A K T}$ for TC. According to Deeter et al. $(2004,2010)$

$\boldsymbol{x}_{\mathrm{ret}}=\boldsymbol{x}_{\mathrm{a}}+\mathbf{A K P} \cdot\left(\boldsymbol{x}-\boldsymbol{x}_{\mathrm{a}}\right)$,

where $\boldsymbol{x}_{\text {ret }}$ is a simulation of retrieved profile in ppb, $\boldsymbol{x}_{\mathrm{a}}$ is an assumed a priori CO profile in ppb, matrix AKP (dimensionless) is the averaging kernel for retrieved profiles, and it is archived together with CO profiles and TC. In Version 4 of MOPITT, AKP is determined for the natural logarithm of VMR (see the MOPITT Version 4 Product User's Guide, http://www.acd.ucar.edu/mopitt/products.shtml). $\boldsymbol{A} \boldsymbol{K} \boldsymbol{T}$ (vector, in molec $\mathrm{cm}^{-2}$ ), can be derived from AKP using a matrix relation:

$A K T=t \cdot \mathbf{A K P}$,

where the vector $\boldsymbol{t}$ is partial TC in layers for the a priori profile $\left(\mathrm{molec} \mathrm{cm}^{-2}\right)$.

For the atmospheric layers $t=2.12 \times 10^{13}$ $\left(\right.$ molec $\left.\mathrm{cm}^{-2} \mathrm{hPa}^{-1} \mathrm{ppb}^{-1}\right) \cdot\left(\boldsymbol{P}_{2}-\boldsymbol{P}_{1}\right) \cdot \boldsymbol{x}_{\mathrm{a}}$, where $\boldsymbol{P}_{2}$ and $\boldsymbol{P}_{1}$ are pressures at the bottom and the top of a layer in $\mathrm{hPa}$, respectively. To normalize the vector $\boldsymbol{A K T}$, it is divided by corresponding vector $\boldsymbol{t}$ (layer by layer):

$A K T N=A K T / t$,

$\boldsymbol{A K T N}$ is a dimensionless vector in contrast to AKP, which is dimensionless matrix.
AKTN for MOPITT and AIRS data are derived from AKP as described above. For IASI-OE, $\boldsymbol{A K T} \boldsymbol{N}$ are delivered in the FORLI-CO data files (see Sect. 2.1).

Retrieval algorithms for ground spectrometers and IASISFA provide TC directly by scaling a priori profile. AKTN were calculated using a set of TC retrievals from simulated spectra for profiles with known perturbations in layers; a priori in all retrievals was the same (unperturbed). In this case, $\boldsymbol{A K T N}$ was calculated using the vector relation:

$\left.\boldsymbol{A K T N}=\left(\mathrm{TC}_{\text {ret }}-\mathrm{TC}_{\text {ret } 0}\right) / \mathrm{TC}_{\text {true }}-\mathrm{TC}_{\text {true } 0}\right)$,

where $\mathrm{TC}_{\text {true } 0}$ is $\mathrm{TC}$ for the standard a priori profile; $\mathrm{TC}_{\text {true }}$ is $\mathrm{TC}$ for the perturbed profile; $\mathrm{TC}_{\mathrm{ret} 0}$ is $\mathrm{TC}$ retrieved from simulated spectrum for the standard a priori profile; $\mathrm{TC}_{\mathrm{ret}}$ is TC retrieved from the perturbed simulated spectrum.

AKTN for four space-based and one ground-based instruments are presented in Fig. 2. A striking difference in shapes of the ground- and space-based spectrometers below $500 \mathrm{hPa}$ is explained by the physics of the radiative transfer in the atmosphere. The sensitivity of retrievals from nadir-viewing TIR sounders is determined by the vertical thermal contrast: a zero contrast or, moreover, a thermal inversion should cause a zero sensitivity. This situation often realizes in the BL, especially, in winter time, during night time, or in the morning. On the contrary, ground-based spectrometers register hightemperature solar radiation absorbed by the Earth's atmosphere. Line shapes are collision-broadened and are formed by the atmospheric layers with different pressures; central parts of lines are dominated by absorption in the upper troposphere, the wings are formed by the lower altitude layers. Strong lines are saturated in the center (i.e. the radiation is 


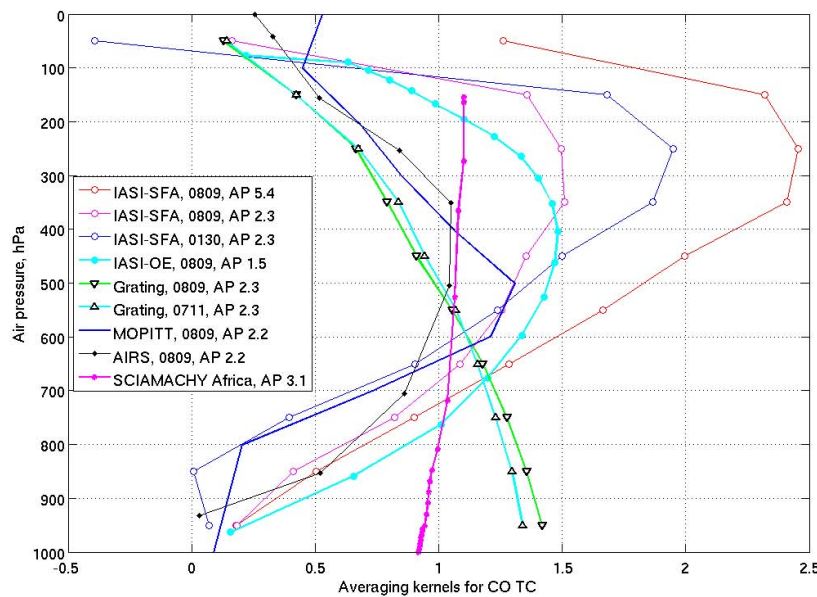

Fig. 2. Normalized averaging kernels for CO TC retrieved from data of space- and ground-based instruments, various days of 2010 (e.g. 0809 corresponds to 9 August 2010). A priori profiles: AP 5.4 corresponds to CO TC equal to $5.4 \times 10^{18}$ molec $\mathrm{cm}^{-2}$, etc. SCIAMACHY AK is adopted from Liu et al. (2011).

totally absorbed), and $\boldsymbol{A K T N}$ (i.e. the sensitivity) is higher in the lower troposphere. For weak lines, which are not saturated in the center, the shape of $\boldsymbol{A K T N}$ may be close to constancy with height. In any case (whether the lines are strong or weak), the sensitivity of solar-viewing spectrometers to the BL is much higher than that of space-based TIR spectrometers.

To estimate what is the impact of AK on the retrieved TC, an IASI-OE profile corresponding to 9 August 2010, Moscow, (see Sect. 3.2.1 below) was convolved with different $\boldsymbol{A K T N}$ and background a priori profiles according to Eq. (1); beforehand, vectors $\boldsymbol{A K T N}$ have been converted into diagonal matrices. Results are listed in Table 1. The first column corresponds to CO TC for the "true" profile. All measured TIR TC should be less than the true value, but IASI-OE is expected to get better results. SCIAMACHY, as a NIR instrument, should supply ideal results, a grating spectrometer should overestimate TC by $41 \%$. It should be noted that the results of grating spectrometers during the period of plume over Moscow are retrieved with a perturbed a priori (step-like profile with polluted lower $300 \mathrm{~m}$ as estimated in Sect. 3.2.1) and, therefore, this overestimation should be offset or minimized.

\subsection{Validation and comparison}

For validation, a period between January 2009 and June 2010 was selected as a period with minimal fire activity in Russia (Fig. 3). Satellite daily data were compared to daily mean CO TC measured from the ground. Figure 3 includes all days, both matching and not matching. For validation, the temporal coincidence criterion was taken the same calendar day (in UTC). Spatial coincidence required a satellite obser-

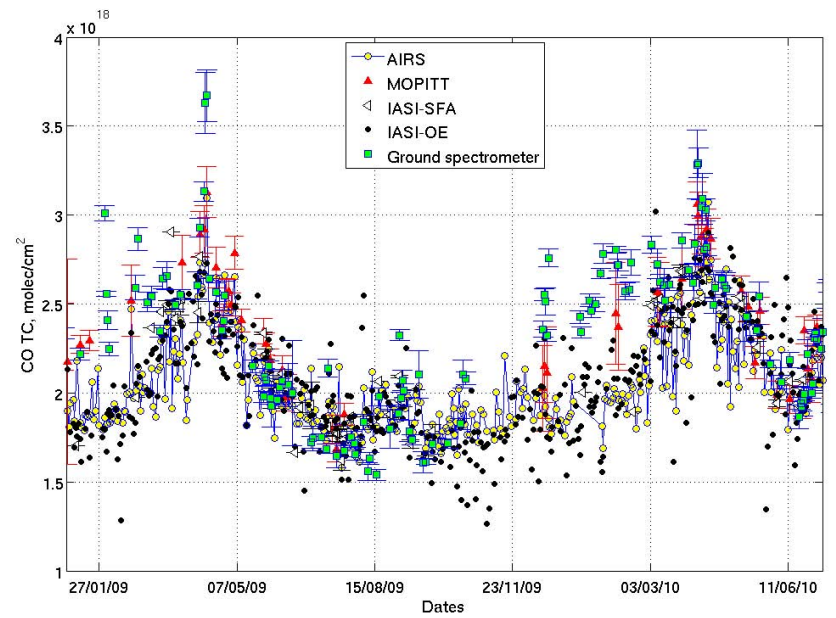

Fig. 3. Daily mean CO TC retrieved from spectra recorded by 3 sounders over grid cell centered at $55.5^{\circ} \mathrm{N}$ and $36.5^{\circ} \mathrm{E}$. Data of Zvenigorod spectrometer play a role of ground truth. Vertical bars are standard deviations of individual measurements.

vation in the same $1^{\circ}$ latitude $\times 1^{\circ}$ longitude grid cell as the ground Zvenigorod station. The maximum misalignment of individual pixels was $150 \mathrm{~km}$.

In accordance with Yurganov et al. (2008, 2010), the largest discrepancies between ground and space instruments were observed in wintertime (near the seasonal CO maximum) due to two main reasons: first, AKTN are lower in wintertime than in summertime in the lower atmosphere (see two cases for IASI-SFA, Fig. 2); second, CO profiles are steeper in wintertime due to more stable $\mathrm{BL}$ and temperature inversions.

Highly important to this research, during summer time and low fire activity, data for all sensors differ from TC measured by grating spectrometer less than $10 \%$. Data averaged over period May-September of 2009, May-June 2010, and, separately, over exactly common periods for all sensors are tabulated in the Table 2; both matching and not matching days are counted. Scattergrams that cover only matching days and both clean and polluted periods illustrate correlations between satellite $\mathrm{CO}$ TC and ground-based data for Zvenigorod, Fig. 4a, b, c, d. It should be noted that the number of matching days was different for different sensors. Among other factors, different cloud filtering played a role: the IASI-SFA filter is the most strict. AIRS has the most loose cloud clearing algorithm. Total columns between 3.5 and $8 \times 10^{18}$ molec cm$^{-2}$ were observed from the ground during the period of fires. It can be concluded that an excellent agreement of all satellite data sets with ground truth before fires changes dramatically to a significant underestimation with the advent of the plume. 
Table 1. CO TC (in units $\times 10^{18}$ molec $\mathrm{cm}^{-2}$ ) calculated according to Eq. (1) with a "true" CO profile for Moscow around 11:30 Moscow local time ( $7 \mathrm{ppm}$ of CO VMR from the surface to $300 \mathrm{~m}$ above the surface; $0.22 \mathrm{ppm}$ between $300 \mathrm{~m}$ and $5000 \mathrm{~m}$ above the surface; then gradual decline down to $0.026 \mathrm{ppm}$ near the tropopause). A priori profiles correspond to those used normally for each data set. AK correspond to Fig. 2. Bottom row is a relation of convolved value to the truth.

\begin{tabular}{lcccccc}
\hline True CO & AIRS & MOPITT & IASI-OE & IASI-SFA & SCIAMACHY & Grating \\
\hline 9.56 & 4.08 & 4.07 & 5.26 & 4.67 & 10.1 & 13.5 \\
1 & 0.43 & 0.42 & 0.55 & 0.49 & 1.05 & 1.41 \\
\hline
\end{tabular}

Table 2. Averages, STD of daily means, and numbers of days for CO TC $\left(\times 10^{18}\right.$ molec $\left.\mathrm{cm}^{-2}\right)$ for the $1^{\circ} \times 1^{\circ}$ degrees grid cell centered at $55.5^{\circ} \mathrm{N}, 36.5^{\circ} \mathrm{E}$ for different data sets for 2009, months May through September, and 2010, months May and June, inclusive. MOPITT data for August and September 2009 are lacking due to a calibration of the instrument. The bottom row is for the period that is common for all 5 data sets.

\begin{tabular}{lrrrrr}
\hline & AIRS & MOPITT & IASI-OE & IASI-SFA & Grating spectrometer \\
\hline Whole warm period & $1.99 \pm 0.22(167)$ & $2.21 \pm 0.28(24)$ & $2.03 \pm 0.28(176)$ & $1.98 \pm 0.24(40)$ & $1.94 \pm 0.23(52)$ \\
Common period & $2.05 \pm 0.22(118)$ & $2.21 \pm 0.28(24)$ & $2.10 \pm 0.28(125)$ & $2.02 \pm 0.25(28)$ & $2.01 \pm 0.21(32)$ \\
\hline
\end{tabular}

\section{Results of measurements during the fires}

\subsection{Satellite data}

Spatial distributions of the Aerosol Index measured by OMI (Torres et al., 1998; http://disc.sci.gsfc.nasa.gov/ Aura/data-holdings/OMI/omaeruv_v003.shtml) and AIRS CO VMR for the $500 \mathrm{hPa}$ level (VMR-500) are presented in Fig. 5 for 9 August 2010. This particular day was the last one when Moscow was totally covered by the plume. The aerosol plume was not as large as the CO plume; aerosol has a shorter residence time in the atmosphere, and, therefore, it is a better proxy for burning areas. A large area for averaging $\left(40-75^{\circ} \mathrm{N}, 30-150^{\circ} \mathrm{E}\right.$, see a square on the map) covering almost all of Russia and including areas obviously without fires (e.g. Siberia) was chosen in an attempt to count as much emitted $\mathrm{CO}$ as possible.

Averaged CO TC values in molec $\mathrm{cm}^{-2}$ (right scale) and burdens in Tg (left scale) for 3 satellite sounders (IASI data were processed using three different techniques) are plotted in Fig. 6. In January-April, 2010, maximum disagreements, reaching 10-15\%, were observed. This can be explained by different vertical sensitivities in conditions of anthropogenically polluted boundary layer and thermal inversions, as well as by different a priori (time-dependent MOPITT a priori are plotted as blue dots, for IASI-OE data uniform a priori TC was around $1.5 \times 10^{18}$ molec $\mathrm{cm}^{-2}$, for AIRS retrievals uniform a priori TC was $2.2 \times 10^{18}$ molec $\mathrm{cm}^{-2}$ ). As of June, disagreements between data of different sounders are less than $10 \%$. During the fire event, especially after 31 July, the data sets practically coincided (excluding systematically lower AIRS data). A noteworthy high IASI-ANN data in
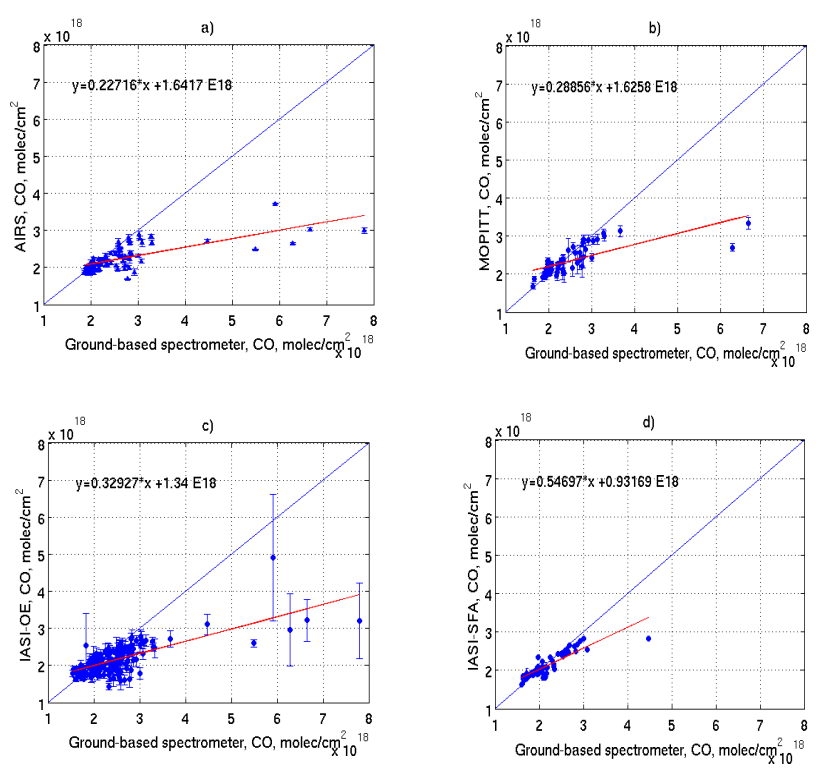

Fig. 4. Scattergrams of CO TC for 3 sounders compared to ground data over Zvenigorod for matching days between January 2009 and September 2010: (a) AIRS; (b) MOPITT; (c) IASI-OE; (d) IASISFA.

July requires further investigation. Generally lower CO burden measured by AIRS during the entire year and during the fire period in particular agrees with independent validation campaigns (Warner et al., 2007; Yurganov et al., 2010). The black line plotted through the lowest points of AIRS data (Fig. 6) illustrates the way the background $\mathrm{CO}$ burden, i.e. the burden expected for the "no fires" case, was assumed. It 


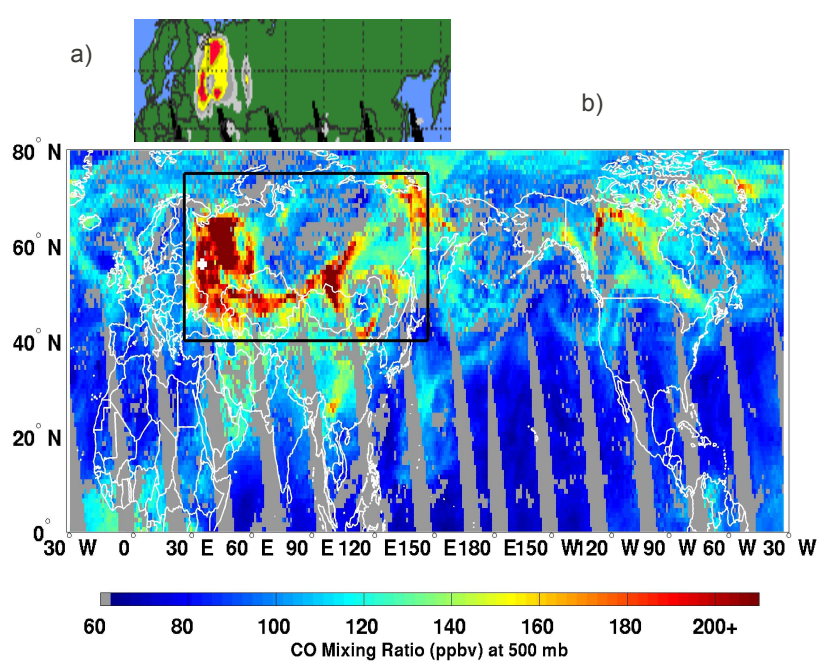

Fig. 5. (a) Map of OMI aerosol index for 9 August 2010. (b) Distribution of CO VMR-500 for 9 August, 2010, according to AIRS. Black square is the area of $\mathrm{CO}$ averaging. Location of Moscow is marked by a white cross.

is drawn through the lowest points of the measured burden in 10-day intervals. This background line was necessary for calculation of pyrogenic $\mathrm{CO}$ burden. Other ways to estimate the background (multi-year averaging, or a burden for the preceding year) differed just a few percent from the chosen one.

\subsection{Ground-based vs satellite comparisons}

\subsubsection{VMR in the surface and boundary layers; the depth of polluted layer}

Figure $7 \mathrm{a}$ and $\mathrm{b}$ (note: different $\mathrm{y}$-axis scales) demonstrate a huge increase in CO VMR in the surface layer both in the city and the rural site. Overall means for the pre-fire period were 224 and $351 \mathrm{ppb}$ in the rural and urban sites, respectively. Before the main fires (June-early July), in the rural area low day-to-day variations were superimposed by a distinct diurnal cycle with a nighttime maximum. Weekly variations with maxima on Friday-Saturday were observed in the city. Stable atmospheric conditions and accumulation of $\mathrm{CO}$ urban emissions during the week explain this pattern. Starting with 2 August, Fig. 7b, CO VMR were increasing rapidly and reached maxima of daily means on 7 August: $9.8 \mathrm{ppm}$ in Moscow, and 8 August: $7.1 \mathrm{ppm}$ in Zvenigorod. According to Witte et al. (2011) polluted air masses came to Moscow/Zvenigorod from south-east after 1 August. During some days with high pollution but no clouds, TC measurements were hampered by strong aerosol dimming that caused instability of sun trackers; no data were obtained in these cases.

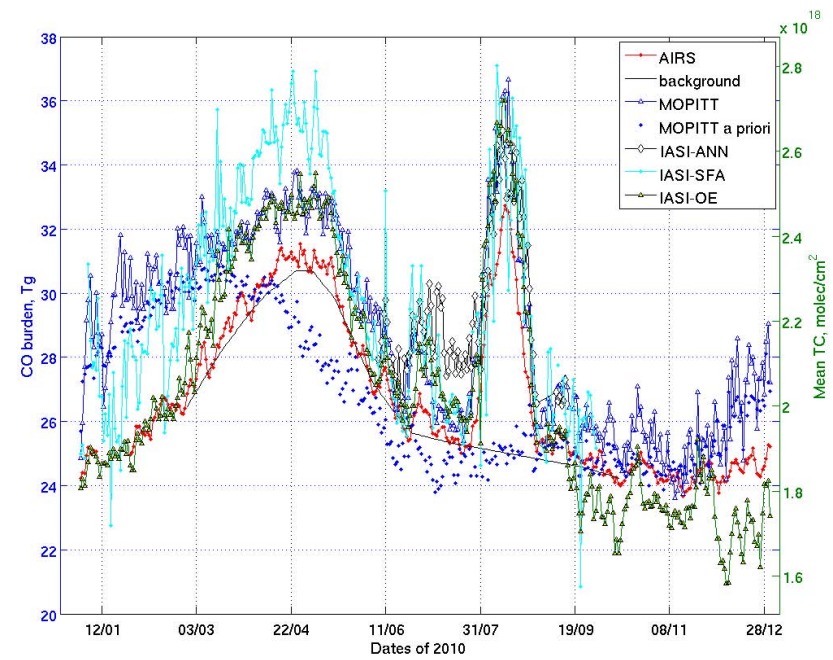

Fig. 6. Averaged over the area $40^{\circ}-75^{\circ} \mathrm{N}, 30^{\circ}-150^{\circ} \mathrm{E} \mathrm{CO}$ TC values (right scale) and corresponding burdens (left scale) according to operational data of MOPITT V4 and AIRS V5, as well as IASI retrieved using 3 different algorithms, in 2010. AIRS background line is shown as an example. The background line represents TC that is expected without wildfires and is plotted through the lowest points of data in 10-days intervals.

To determine the depth of the polluted layer we compiled all available satellite and ground information about $\mathrm{CO}$ on 9 August in Moscow. For characterization of CO VMR in the boundary layer, we used TV tower data averaged over the altitudes between 0 and $248 \mathrm{~m}$ above the ground. TV tower VMR, surface MSU VMR, and TC of the ground-based Moscow spectrometer are plotted in Fig. 8. Throughout this day, a general decline in $\mathrm{CO}$ was observed both for VMR and TC from the ground spectrometer. This decline agrees with a decline in IASI-OE TC data for the Moscow grid cell: $6.85 \pm 1.84$ (9) around 11:27, $3.35 \pm 0.25$ (4) around 21:17, and 3.11 \pm 0.48 (4) around 22:56 of Moscow local time. TC is in units $\times 10^{18}$ molec $\mathrm{cm}^{-2}, \pm$ STD of individual retrievals and number of retrievals in parentheses. A systematic $2 \mathrm{ppm}$ difference in VMR between TV tower and MSU may be explained by different locations; also lower VMR near the surface may be due to remoteness of the source of pollution.

The availability of satellite and ground-based measurements gives an opportunity to estimate the depth of the polluted layer: (1) IASI-OE specifies VMR for the free troposphere above the polluted layer for 9 August, $55.94837^{\circ} \mathrm{N}$, $37.82514^{\circ} \mathrm{E}, 11: 26: 46$ of Moscow local time; (2) CO data from TV tower characterize bottom $200 \mathrm{~m}$ of the atmosphere, (3) the ground-based spectrometer measures $\mathrm{CO}$ TC. Spectral fitting and scaling of a set of 13 a priori profiles were performed for two ground-based spectra at 11:24 and 14:38, Moscow local time (UTC+4h) (see Fig. 9). The first run (the depth $=0$ ) was carried out with the "background" distribution: $223 \mathrm{ppb}$ from the surface to 
a)

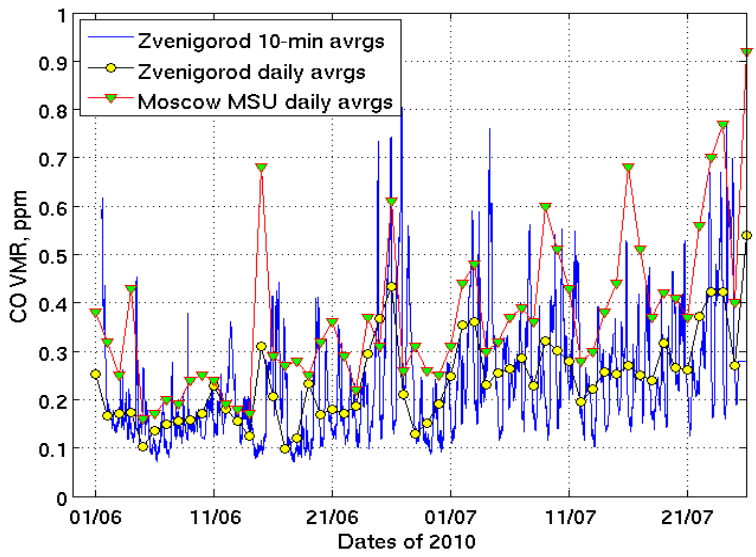

b)

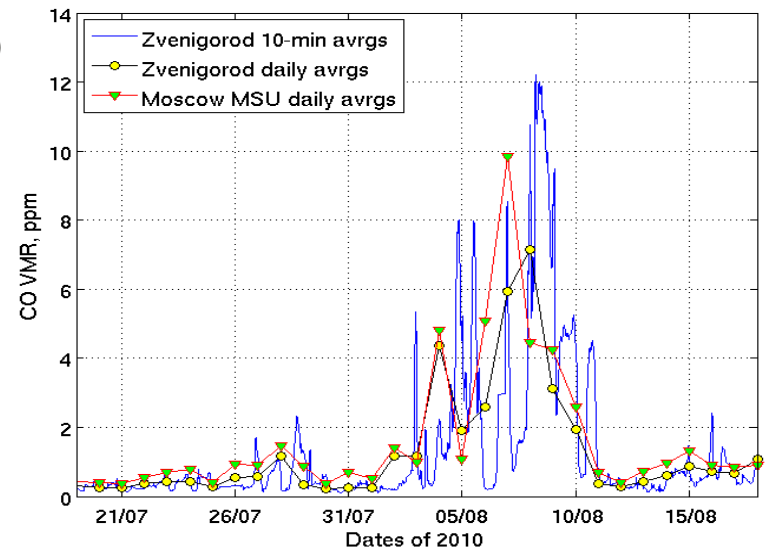

Fig. 7. CO VMR in the surface layer in Moscow and a rural site, Zvenigorod: (a) before, and (b) during the fire period. Note the different scales. Ticks correspond to 12:00 Moscow local time (UTC+4 h)

$500 \mathrm{hPa}$, and a gradual decline above, according to IASI data $\left(\mathrm{TC}=3.87 \times 10^{18}\right.$ molec $\left.\mathrm{cm}^{-2}\right)$. For the second run, VMR in the bottom $50 \mathrm{~m}$ thick layer of the atmosphere was set equal to the average of CO VMR from TV tower (7 ppm for the AM spectrum and $3.5 \mathrm{ppm}$ for the PM spectrum). For the third run, the depth of polluted air was increased by $50 \mathrm{~m}$ with the same VMR, and so on. TC in these a priori profiles were increasing due to the changing depth of the layer polluted with the same VMR. These profiles were scaled until the calculated $\mathrm{CO}$ spectra fit the measured spectra. If the scaling factor is equal to 1 (in other words, retrieved $=$ a priori), the assumed depth of the polluted layer may be considered close to the real one. Both runs led to the depth of $360 \mathrm{~m}$ (the intersection of two lines with the same color). Unfortunately, this method is highly uncertain due to the variability of CO VMR in both horizontal and vertical directions. However, a useful conclusion can be drawn: the depth of polluted air over Moscow on 9 August 2010 did not exceed several hundred meters. A similar depth of $\sim 200 \mathrm{~m}$ was obtained using the same procedure for Zvenigorod, 4 August 2010.

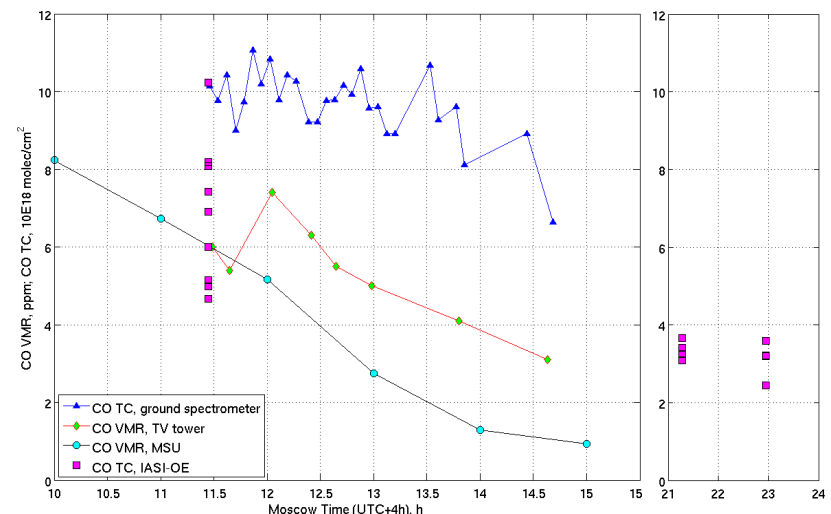

Fig. 8. Moscow, 9 August 2010. CO TC retrieved from spectra of ground spectrometer (blue triangles) are plotted in units $\times 10^{18}$ molec $\mathrm{cm}^{-2}$. Also plotted are CO VMR in ppm in the surface layer, MSU, and the data for the TV tower averaged over the altitudes $0-248 \mathrm{~m}$ above the surface. Squares correspond to IASI$\mathrm{OE}$ data for the Moscow $1^{\circ} \times 1^{\circ}$ grid cell centered at $55.5^{\circ} \mathrm{N}$ and $36.5^{\circ} \mathrm{E}$.

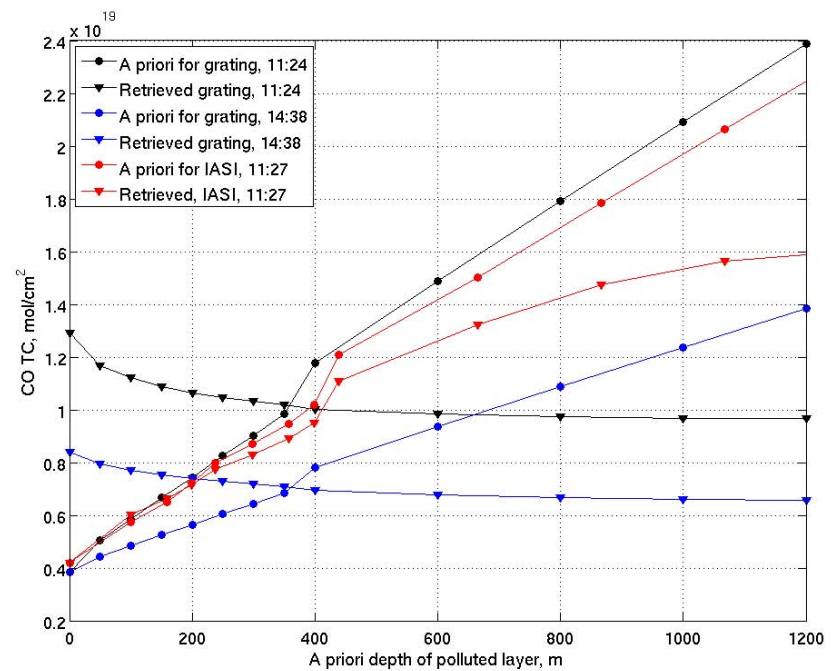

Fig. 9. Moscow, 9 August 2010. Ground-based grating total columns for $\mathrm{CO}$ a priori profiles (circles) and retrieved TC (triangles) before noon (11:24) and after noon (14:38). A priori profiles differ by the depth of polluted air with VMR 7 and $3.5 \mathrm{ppm}$. Intersections of lines of the same color (blue and black) correspond to the most probable depths of polluted air and the retrieved TC. IASI-SFA (red) does not ensure a definite solution.

The algorithm described above works well for the ground solar-tracking spectrometer but does not work for a TIR nadir-looking spectrometer, which can be illustrated by a failed attempt to do the same with the same spectrum of IASI using the SFA algorithm. It was fitted by the calculated spectra with the same set of a-priori profiles (red lines in Fig. 9). Calculations were performed using the kCARTA radiative transfer algorithm (DeSouza-Machado et al., 1997). 


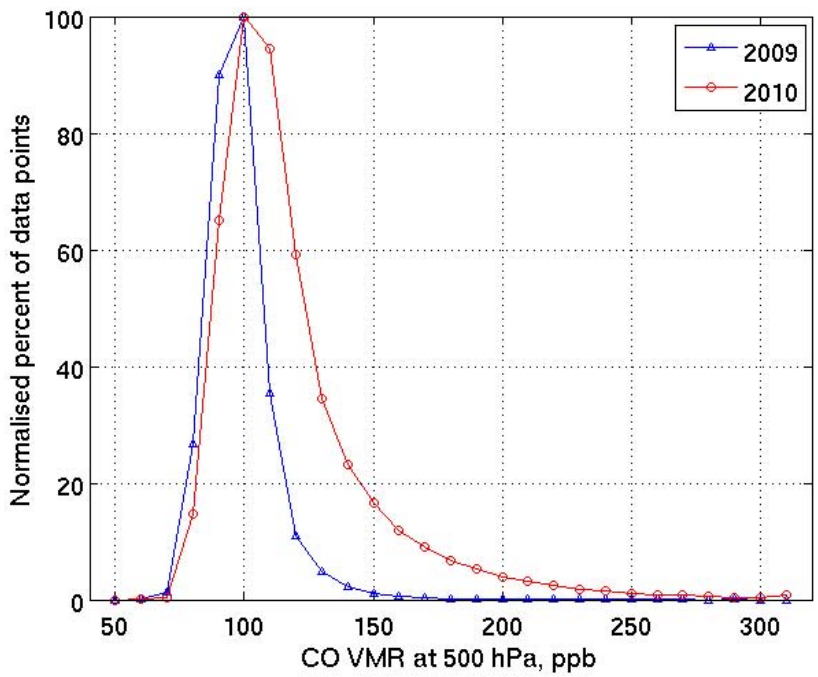

Fig. 10. Histograms of CO VMR-500 retrieved from AIRS spectra for Russia during the period between 2 August and 9 August for 2009 and 2010. Two plume threshold values, $150 \mathrm{ppb}$ and $170 \mathrm{ppb}$, are used to calculate the plume areas in 2010.

In contrast to the ground spectrometer, we see that the TC retrieved from the IASI spectrum was increasing along with the increasing a priori, a direct consequence of low sensitivity of IASI channels to the concentrations in the BL (see Sect. 2.3 and corresponding figures).

\subsubsection{Extrapolation of Moscow results onto the entire plume}

TC ground measurements in the Moscow area make it possible to estimate the missing $\mathrm{CO}$ (MCO), i.e. the difference between TC for two ground-based spectrometers, and satellite data. TC for ground spectrometers were retrieved using a priori profile with $4 \mathrm{ppm}$ of $\mathrm{CO}$ in the bottom 300 -m-thick layer. In this section, MCO will be extrapolated onto the entire plume. First, the area of the plume needs to be determined.

AIRS V5 is probably a less accurate $\mathrm{CO}$ data set than MOPITT V4, but it ensures $100 \%$ daily coverage of the Russian territory, and its data can be used for quantification of the plume area. The latter is determined here as the area with satellite-derived VMR-500 larger than a specified threshold. The threshold for VMR-500 can be determined by comparing periods with and without fires, e.g. 2010 and 2009 over Russia. In 2009, the CO VMR-500 over the entire area of Russia had a narrow and close-to-normal frequency distribution with a maximum near $100 \mathrm{ppb}$ (Fig. 10, blue line); there were not many numbers of measurements above $130 \mathrm{ppb}$, and practically no data above $150 \mathrm{ppb}$. Conversely, a 2010 plot (red line) reveals many cases with VMR-500 $>150 \mathrm{ppb}$.

In this section the Moscow metropolitan area (that included Zvenigorod) for the satellite data is chosen as 54.0- a)

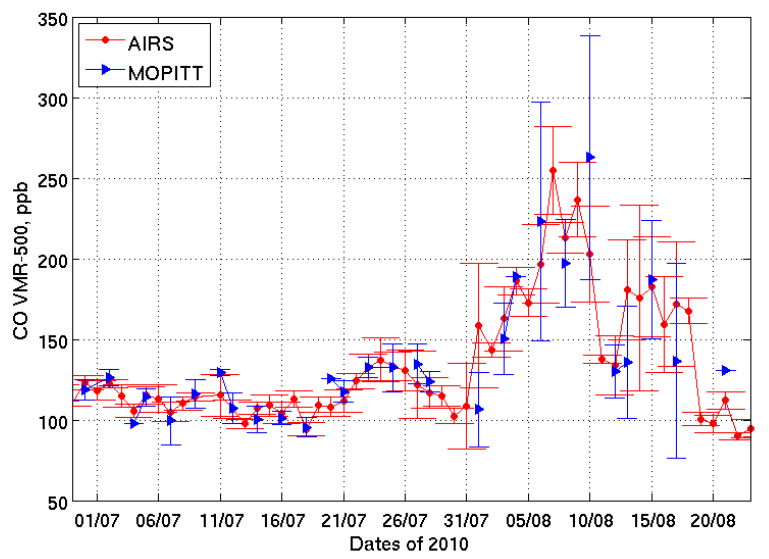

b)

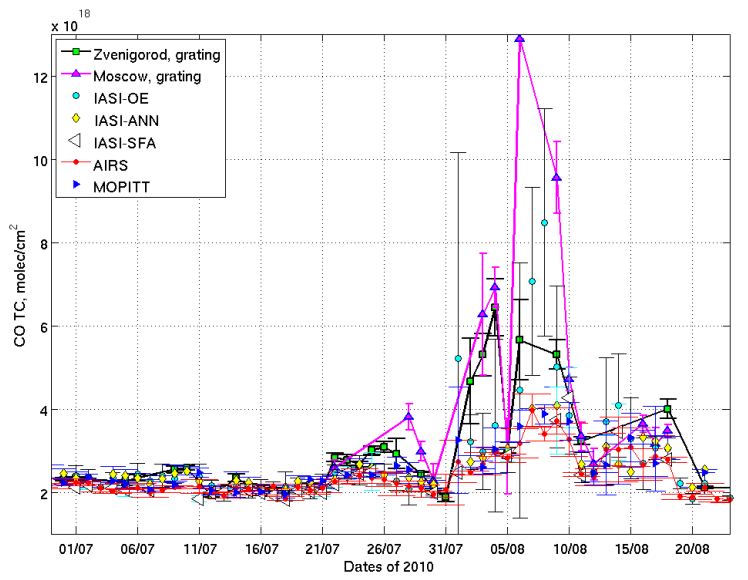

Fig. 11. VMR for $500 \mathrm{hPa}$ (a) and CO TC (b) averaged over the Moscow metropolitan area $\left(54.0^{\circ}-58.0^{\circ} \mathrm{N}, 36.0^{\circ}-38.0^{\circ} \mathrm{E}\right)$ in comparison to ground-based daily TC data.

$57.0^{\circ} \mathrm{N}$ and $36.0-38.0^{\circ} \mathrm{E}$ (the area coincides with the symbol of Moscow on the map of Fig. 5). Daily and spatial averages of VMR-500 are presented for AIRS and MOPITT in Fig. 11a. VMR-500 for both AIRS and MOPITT exceeded $150 \mathrm{ppb}$ in the Moscow/Zvenigorod area between 2 and 9 August 2010. We consider $150 \mathrm{ppb}$ as the most likely option for the plume boundary; $170 \mathrm{ppb}$ option was used as a more conservative case.

Mean values for two ground sites (in $\times 10^{18}$ molec cm $^{-2}$, number of spectra in parentheses) for 2-9 August (Fig. 11b) are: Moscow 7.45 (75); Zvenigorod 5.43 (58); combined 6.31(133). Zvenigorod displays lower pollution since its location was less impacted by the plume than Moscow. The mean TC measured by satellite sounders in the specified $3^{\circ}$ latitude $\times 2^{\circ}$ longitude square (in $\times 10^{18}$ molec $^{-2}$ ) are MOPITT 3.34 ; AIRS 3.15; IASI-OE 4.7. Larger values retrieved from MOPITT in comparison to AIRS data are explained by its slightly higher sensitivity to the BL and, to some extent, a possible bias in the algorithm (see Table 2). IASI-OE TC were in a better agreement with ground truth, than two other data sets. A better sensitivity to the bottom 
layers is the most likely explanation of that (Fig. 2 and Table 1). Insufficient number of IASI-ANN and IASI-SFA points did not allow one making such estimates for them. Finally, MCO (ground minus satellite) is estimated as 2.97 for MOPITT, 3.16 for AIRS, and 1.61 for IASI-OE (TC values are in $\times 10^{18}$ molec $^{-2}$ ).

The plume areas for three limits: 130,150 , and $170 \mathrm{ppb}$, are plotted in Fig. 12a. AIRS grid cells with no data (e.g. cloudy pixels) but located inside the plume were included in the area calculations using the criterion of 2, 3, or 4 adjacent "plume" grids. The area with no data but included into the plume amounts to $10 \%$ of total plume area. Plume periphery has VMR-500 between 130 and 150 ppb ( greenish pixels on the map of Fig. 5b).

Primary CO burdens emitted by fires (measured minus background, see Sect. 3.1 for the background definition) for four data sets are plotted by different symbols in Fig. 12b. Lines are burdens added by MCO for AIRS and MOPITT in assumption of $150 \mathrm{ppb}$ as a plume boundary.

Accuracy of satellite retrievals for the plume periphery (VMR-500 between 130 and $150 \mathrm{ppb}$ ) may be quantified as well. These values of VMR-500 were measured by AIRS over the Moscow area between 23 July and 27 July. During this period, there were ground TC measurements in Zvenigorod as well (but, unfortunately, not in Moscow itself). For the Zvenigorod grating, MOPITT, and AIRS, the TC were $2.89,2.50$, and $2.33 \times 10^{18}$ molec $\mathrm{cm}^{-2}$, respectively. Therefore, MCO for MOPITT and AIRS were 0.39 and $0.56 \times 10^{18}$ molec $\mathrm{cm}^{-2}$, significantly less than MCO for the "fire week". Inclusion of the plume periphery changes the corrected burden only by 6.0 and $6.8 \%$ for MOPITT and AIRS and this was neglected.

\section{Mass balance inverse modeling of the Russian fire - method, testing, and $\mathrm{CO}$ emission in 2010}

Similarly to the approach used in the previous papers (Yurganov et al., 2004, 2005, 2008, 2010), the emission of $\mathrm{CO}$ is derived from its burden anomaly inside some specified area. This is a simple and fast technique to estimate smoothed daily $\mathrm{CO}$ emission rates and total emitted $\mathrm{CO}$. Here, this technique is used primarily as a convenient tool to determine the sensitivity of a top-down estimate to the error of a satellite-borne TIR sounder. This model can not accurately assess emission rates day-by-day in principle, just emissions smoothed over several days (10 days in this paper). A reason for this is an inevitable assumption about a horizontally well mixed $\mathrm{CO}$ inside the box. In reality, the transport of pollutants through the boundaries of the domain is irregular and depends on the large-scale turbulence. So, a more sophisticated transport model is necessary for more accurate modeling.

Any anomaly is determined as a difference between the measured burden and the "background", i.e. the burden that a)

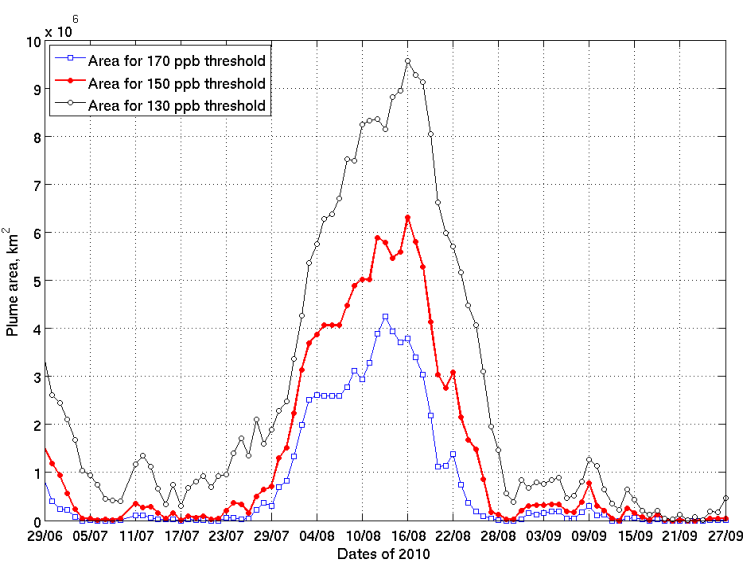

b)

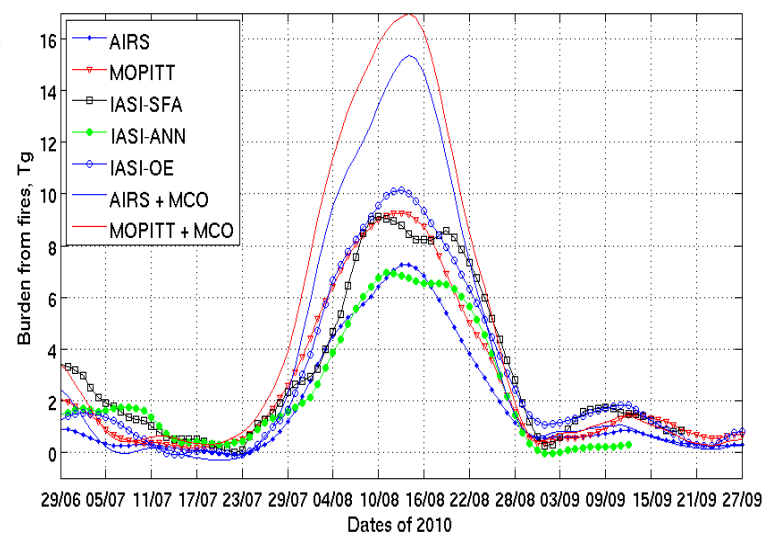

Fig. 12. (a) Plume area for 3 selected boundaries $(170,150$, and $130 \mathrm{ppb}$ ) over Russia in 2010. (b) CO extra burden due to fires (total burden subtracted by background). First five lines are for standard retrieval. Last two lines demonstrate the effect of correction for $\mathrm{MCO}$ in the case of $150 \mathrm{ppb}$ as a boundary of the plume.

would be without fires. The line of background $\mathrm{CO}$ burden is plotted through the lowest points of the measured burden in 10-day intervals, and corresponds to the black line in Fig. 6 for the AIRS case, plotted as an example.

The daily anomalies of the $\mathrm{CO}$ global emission rate $\boldsymbol{P}$ $\left(\mathrm{Tg} \mathrm{CO} \mathrm{day}{ }^{-1}\right)$ are connected to the daily change in the burden anomaly $d B / d t\left(\mathrm{TgCO} \mathrm{day}^{-1}\right)$, daily burden anomaly $B$ (Tg CO), and time parameters for the sinks TAU (days): $[\mathrm{OH}]$ oxidation $\mathrm{TAU}_{\text {chem }}$ and wind removal TAU $\mathrm{U}_{\text {trans }}$ :

$\boldsymbol{P}=d B / d t+B / \mathrm{TAU}_{\text {chem }}+B / \mathrm{TAU}_{\text {trans }}$

$\mathrm{TAU}_{\text {chem }}$ is calculated from the vertical distributions of monthly mean $[\mathrm{OH}]$ tabulated by Spivakovsky et al. (2000). In the mid-latitudes, in contrast to the tropics, CO loss from transport prevails over oxidation; TAU $\mathrm{U}_{\text {trans }}$ is estimated using a 3-D chemistry/transport model GEOS5 driven by assimilated meteorological data from the NASA/GSFC/GEOS/GMAO (Duncan et al., 2007) without chemistry. 
a)

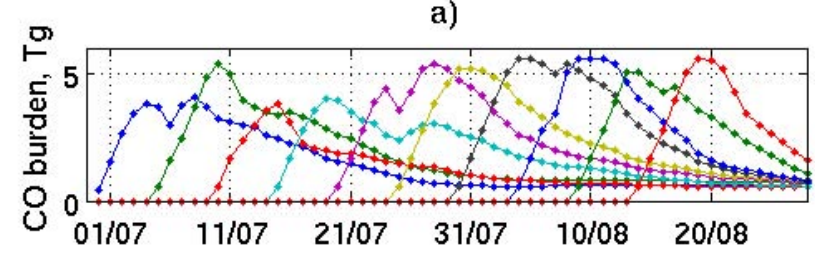

b)

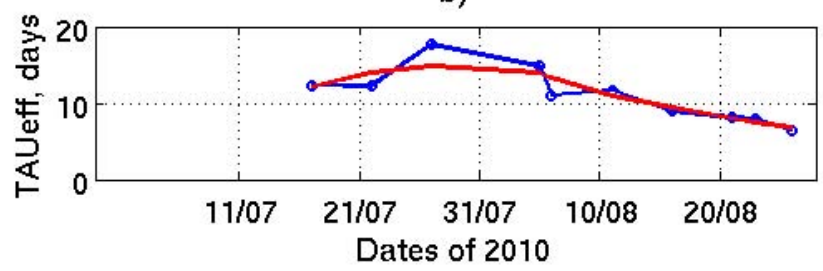

Fig. 13. (a) Simulated pyrogenic CO burden B over Russia in 2010 for 5-days-long idealized fires emitted $1.11 \mathrm{Tg}^{\mathrm{day}}{ }^{-1}$ for 10 cases; 1 st case is for 1-5 July, 2nd for 6-10 July, etc. (b) Effective time parameter $\mathrm{TAU}_{\text {trans }}$ for the exponential decay of $\mathrm{CO}$ burden after the termination of simulated fire. Each point is averaged over periods of 12-16 days long. The red line is a smoothing approximation.

The model runs with no biomass burning emissions since 1 July 2010 except for the idealized fire sources of $1.11 \mathrm{Tg}$ per day over a $3^{\circ}$ latitude by $3.75^{\circ}$ longitude region centered on $55^{\circ} \mathrm{N}, 45^{\circ} \mathrm{E}$. The fire sources are tracers of 5-day periods - essentially, the first run represents the fire emissions for 1-5 July, the second represents the fire for 6-10 July, etc. This provides an indication of how long $\mathrm{CO}$ mixing ratios remain elevated after burning and how fast they relax afterwards (Fig. 13a). In Fig. 13b e-folding parameters TAU $\mathrm{U}_{\text {trans }}$ for time spans with durations between 12 and 16 days after the fire halts are plotted. The highest $\mathrm{TAU}_{\text {trans }}$ (the lowest transport) was observed during the first half of the real fire period; during the second half of the period, the intensity of air circulation was gradually increasing (TAU $\mathrm{Trans}_{\text {simish- }}$ ing).

These model simulations give an opportunity to test the performance of the mass balance inverse modeling. All burdens presented in Fig. 13a were taken as "measured" and the emission was retrieved from those. One example of the retrieval $\left(1.11 \mathrm{Tg} \mathrm{day}^{-1}\right.$ emission was set between days 207 and 211) is plotted in Fig. 14a. The retrieved daily emission (blue dots and line) in the maximum $\left(1.3 \mathrm{Tg} \mathrm{day}^{-1}\right)$ exceeds the input value by $17 \%$, or, averaged over 10 cases, $(20 \pm 13) \%$. Small negative values between 4 August and 10 August have no physical meaning and are the result of errors in the model; however, this is tolerable for such a simple model. A similar effect appears in Fig. 14b. The total emitted CO is overestimated by $(30 \pm 17) \%$. This overestimation could be taken in account in comparisons with other methods. a)

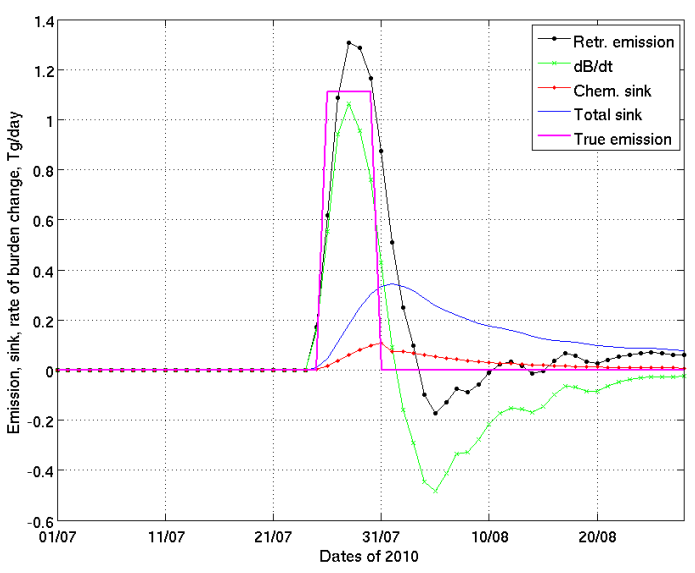

b)

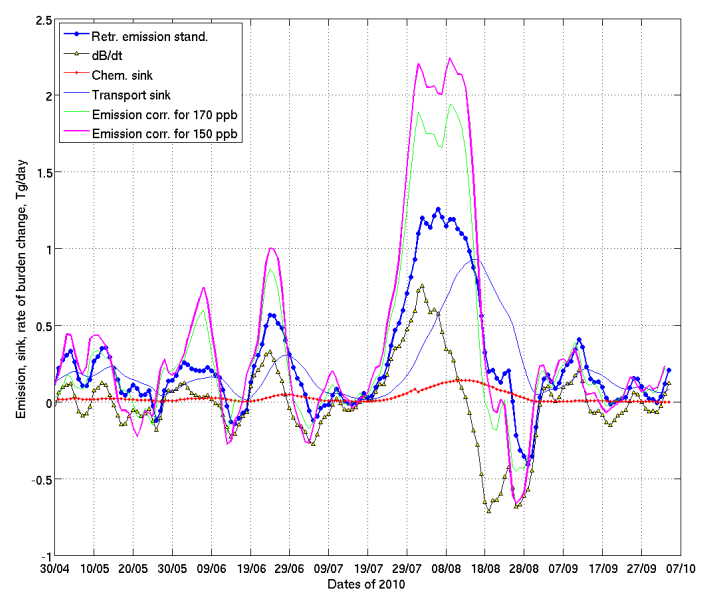

Fig. 14. (a) A test of the mass balance model. Magenta line is the emission of simulated fire ("true emission") in the central Russia with $1.11 \mathrm{Tg} \mathrm{day}^{-1}$ (5.55 Tg of total emission). CO burden calculated by the GEOS-5 see in Fig. 13a. $[\mathrm{OH}]$ for the chemical sink is according to Spivakovsky et al. (2000). The transport sink is calculated as $B / \mathrm{TAU}_{\text {trans }}$ (see Fig. 13b for TAU trans). The retrieved emission rate is plotted as the blue line and dots. Retrieved total emitted CO for this case is $7.67 \mathrm{Tg}$ that is $38 \%$ larger than that initially set in the model. (b) The $\mathrm{CO}$ fire emission retrieved from MOPITT V4 data for 2010. The blue line with dots is for measured burdens. Measured burdens were added by MCO, and corrected emissions are plotted for two assumptions on the plume boundary: VMR-500 $>150 \mathrm{ppb}$ and VMR-500 > 170 ppb.

First of all, $\mathrm{CO}$ emitted by Russian fires was estimated using the satellite remote sensing data without any correction ("standard" case). The retrieved CO daily emission rates and components of $\mathrm{CO}$ cycle for the MOPITT case are presented in Fig. 14b as an example. The estimates for this sounder and for other data sets are tabulated in Table 3. MCO, as determined above for the Moscow-Zvenigorod area, are added to the retrieved $\mathrm{CO}$ burden for the entire plume. Two cases for the plume boundaries have been used in the calculations, but the value of $150 \mathrm{ppb}$ fits typical Moscow conditions better. 
Table 3. CO emission rates derived from the data of space sounders using mass balance box modeling for the standard case (as is), and for the burdens corrected for MCO. Corrections for MCO were applied to the satellite data inside the plume; the boundaries of the plume were specified by $150 \mathrm{ppb}$ (main case that highlighted in bold) and $170 \mathrm{ppb}$ (supplementary case).

\begin{tabular}{lrrr}
\hline $\begin{array}{l}\text { Data set and } \\
\text { boundary VMR-500 } \\
\text { for the plume }\end{array}$ & $\begin{array}{r}\text { Total CO emitted } \\
\text { between 15 July } \\
\text { and 31 August, Tg }\end{array}$ & $\begin{array}{r}\text { Maximum daily } \\
\text { emission rate, } \\
\text { Tg day }\end{array}$ & $\begin{array}{r}\text { MCO, } \\
\times 10^{18} \\
\text { molec cm }^{-2}\end{array}$ \\
\hline MOPITT V4, standard & 22.3 & 1.25 & 3.34 \\
AIRS V5, standard & 16.8 & 1.07 & 3.15 \\
IASI OE, standard & 26.2 & 1.5 & 1.61 \\
IASI SFA, standard & 24.8 & 1.8 & ND \\
IASI ANN, standard & 18.1 & 1.09 & ND \\
MOPITT, 150 ppb & $\mathbf{3 9 . 6}(\mathbf{1 . 8})$ & $\mathbf{2 . 2 ( 1 . 8 )}$ & NA \\
MOPITT, 170 ppb & $32.4(1.4)$ & $1.9(1.5)$ & NA \\
AIRS, 150 ppb & $\mathbf{3 3 . 7}(\mathbf{2 . 0})$ & $\mathbf{2 . 2}(\mathbf{2 . 0})$ & NA \\
AIRS, 170 ppb & $26.3(1.6)$ & $1.9(1.8)$ & NA \\
IASI OE, 150 ppb & $\mathbf{3 5 . 6 ( 1 . 4 )}$ & $\mathbf{2 . 1}(\mathbf{1 . 4})$ & NA \\
IASI OE, 170 ppb & $31.6(1.2)$ & $1.9(1.3)$ & NA \\
\hline
\end{tabular}

Notes:

1. In parentheses are given ratios of emission estimates to the standard values (first three rows in the table).

2. For comparisons to other techniques, the emissions may be diminished by 20-30\% because of an error introduced by the model (Sect. 4.1 ).

3. ND: not determined due to insufficient data. NA: not applied.

Emission rates estimated from corrected MOPITT, AIRS, and IASI-OE data are plotted in Fig. 15. Also plotted are bottom-up emission estimates (daily and smoothed) obtained by Fokeeva et al. (2011) using Terra/MODIS and Aqua/MODIS burned areas and inventory technique proposed by Wiedinmayer et al. (2006) and Roy et al. (2008). All of them have similar shapes with two maxima. Total emitted $\mathrm{CO}$ in July-August was estimated as 29.8 and $36.1 \mathrm{Tg}$ for Aqua/MODIS and Terra/MODIS, respectively. These estimates are inside the range of our top-down estimates.

A CHIMERE CTM was used in conjunction with Aqua/MODIS FRP data and MOPITT CO VMR (Konovalov et al., 2011) for quantification of $\mathrm{CO}$ emission. The model emissions were optimized by comparing with MOPITT VMR at $900 \mathrm{hPa}$ and surface measurements of CO VMR in Moscow. CO total emission estimated by Konovalov et al. (2011), 9.7 Tg CO, was almost 4 times less than our assessments and the inventory result cited above. Reasons for this are unknown.

\section{Discussion}

Validity of satellite-borne sounders for source areas (like wildfires or strong anthropogenic pollution) is a problem that has not been solved completely yet. There are just few ground-based TC measurements in fire areas, as well as surface data for these events. For instance, Wendler et al. (2010) reported high CO VMR observed in downtown Fairbanks, Alaska (USA), during the 2004 Alaskan wildfire

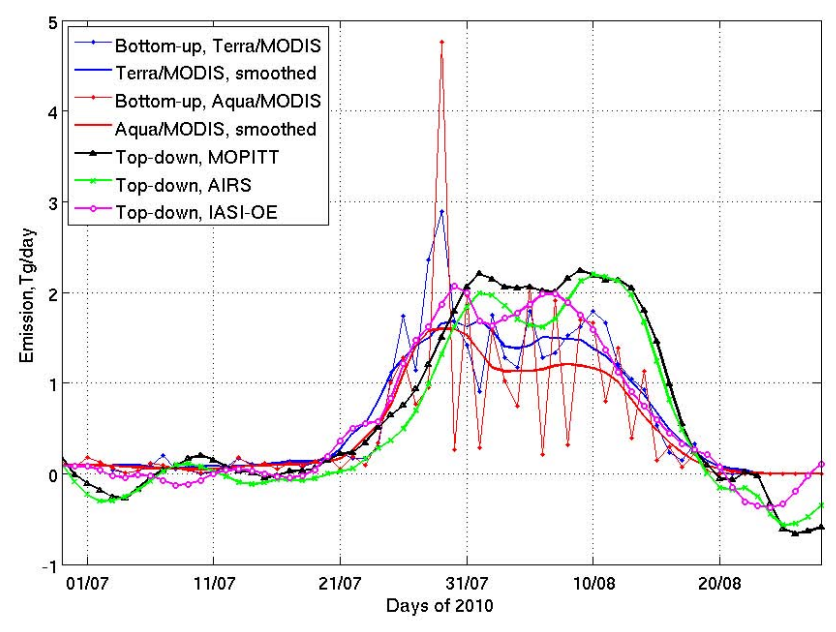

Fig. 15. A comparison of top-down and bottom-up CO emission estimates. Daily emission rates are calculated using inventory technique by Fokeeva et al. (2011) with burned areas from two MODIS instruments; for a better comparison they were smoothed by us.

season, which was the worst on record for that area. Strong northerly winds advected pollution into Fairbanks from the fire, located to the North of the city. The maximum CO VMR of $10.3 \mathrm{ppm}$ was recorded on 28 June 2004, resulting in an 8$\mathrm{h}$ average VMR of $9.2 \mathrm{ppm}$. During the day, the 8-hourly averaged CO VMR dropped to $8.6 \mathrm{ppm}$. Total CO emitted from the fire was estimated as $30 \pm 5 \mathrm{Tg} \mathrm{CO}$ using inverse modeling and MOPITT v3 data (Pfister et al., 2005). This case looks very similar to the Moscow pattern. 
The low sensitivity of TIR sensors to the BL prevents an accurate determination of $\mathrm{CO}$ emitted by fires. The most reasonable way to resolve this problem is using satellite spectrometers with NIR spectral range and reflected solar radiation. However, reliable data of this sort are still unavailable or are being developed (Worden et al., 2010). In this situation, preliminary estimates of the error based on a few days with ground-based TC data matching satellite measurements are helpful.

An excellent agreement in retrieved TC between different satellite sounders, ground spectrometer, and different retrieval techniques during warmer months and no fires (Table 2) is noteworthy. During the fire the agreement between TIR sensors is also not bad. We consider this a consequence of the same spectral range: all algorithms are reliable. However, for strong fires IASI-OE data were markedly better that other data sets; its MCO was less than MCO for MOPITT and AIRS (Table 3). A decisive role of a better sensitivity for the BL is confirmed by comparison of AK (Fig. 2 and Table 1). A better spectral resolution of IASI probably played a role in this.

However, there is an alternative explanation of this difference, namely differences in OE procedures. As Deeter et al. (2010) noted, extreme CO concentrations over source areas pose a special challenge to retrieval algorithms. For example, some MOPITT V3 retrievals over Indonesian fires of 2006 consistently failed because iterated VMR values exceeded the largest values in the training set used to develop the MOPITT radiative transfer model. The set was extended in the MOPITT V4, but this effect may be still important. So, a more specific comparison between MOPITT and IASI$\mathrm{OE}$ on a case-by-case basis is necessary for strong wildfire events.

The low sensitivity to the BL is illustrated by a failed attempt to retrieve the depth of polluted layer using IASI spectra (Fig. 9): the CO channels in the calculated spectra are hardly sensitive to the $\mathrm{CO}$ change in the BL; the retrieved amounts are stuck at the first guess. A similar effect is observed during winter months over cold areas of Eurasia (Fig. 6): MOPITT data coincide with a priori during the coldest season.

A better performance could be expected for a NIR sounder. According to Table 1, SCIAMACHY should detect CO TC over Moscow properly. Unfortunately, such measurements for 2010 are still unavailable. SCIAMACHY data for African and Brazilian fires in 2004 and 2005 (Liu et al., 2011) do not confirm so high TC over wildfires.

A ground-based spectrometer allows estimating the depth of polluted layer if the additional information on the VMR in the BL is available (Fig. 9). Unfortunately, $\mathrm{CO}$ variations in the BL both throughout the city and vertically are huge; $\mathrm{CO}$ variability above the polluted layer is large as well. Thus, a depth of $360 \mathrm{~m}$ (for the assumed step-like CO distribution) is just a rough estimate for this. Moreover, we emphasize that this depth is evaluated for Moscow. Much evidence (Fokeeva et al., 2011; Witte et al., 2011) shows that the Moscow area was impacted significantly by low-temperature peat fires; the depth of polluted layer is usually lower for this case than that for forest fires, especially during the flaming stage (Potter et al., 2002).

Having Moscow's MCO represent the entire plume is a matter of concern. We assumed that "missing" CO TC over Moscow during the days with VMR-500 > $150 \mathrm{ppb}$ can be applied to the rest of the plume. However, it should be noted that during the entire period of Russian fires (almost a month) the Moscow/Zvenigorod sites were covered by the plume only for a week between 2 August and 9 August. Further, during this week, CO VMR-500 over Moscow/Zvenigorod, according to AIRS, was between 150 and $260 \mathrm{ppb}$. Meanwhile, AIRS CO VMR-500 in the core parts of the plume reached $300 \mathrm{ppb}$ (Figs. 5, 10). These pixels could be over active fires, and TC could be much higher than over Moscow. Also, a few days with the highest pollution both in Moscow and Zvenigorod between 2 and 9 August were missing: during these days with no clouds the solar trackers could not track the Sun properly due to a reduced illumination. The inclusion of these days would most likely increase our estimates of MCO. All these factors lead to underestimation of the emission. On the other hand, testing the mass balance algorithm shows 20-30\% overestimation (Sect. 4.1). Finally, the total $\mathrm{CO}$ emission is estimated as $36-40 \mathrm{Tg}$, and the error may be estimated as $\pm 30 \%$.

According to the mass balance considerations, correcting the $\mathrm{CO}$ burden for the MCO leads to doubling emission obtained from AIRS data and almost doubling those from MOPITT data. It should be noted, however, that this statement refers to the inversion technique used in this paper. Other inverse modeling algorithms may work better (or worse). Anyway, we believe that the underestimation of CO TC over the Russian fires by satellite TIR sounders can be applied to other important wildfire events, e.g. African, Brazilian, and Indonesian tropics as well.

\section{Conclusions}

1. The Moscow area was strongly impacted by the plume of wildfires in early August 2010. Two spectrometers deployed in Moscow and in a rural site registered factor of 2 or 3 higher CO TC than CO TC retrieved from data of 3 TIR space-based sounders. IASI-OE retrievals look better then others.

2. Data of all sounders, all algorithms, and the ground spectrometer during warmer month of the year and without fires are in excellent agreement.

3. Supplemental CO VMR measured in the surface layer and on the TV tower were an order of magnitude higher during the period of plume than during the preceding period. 
4. A combination of CO VMR at the TV tower with spectroscopically measured from the ground $\mathrm{CO} \mathrm{TC}$ and VMR above the polluted layer by IASI-OE revealed the depth of the polluted layer over Moscow as $\sim 360 \mathrm{~m}$ on 9 August 2010.

5. Data of MOPITT V4 and IASI (3 different retrieval algorithms) averaged over the Russian territory during August 2010 have been found to be in good agreement during the period of fires: differences did not exceed $3 \%$. TC AIRS V5 data were systematically biased 3$5 \%$ downward.

6. Averaged underestimation of TC for the Moscow area (missing CO) have been found to be between 1.6 and $3.3 \times 10^{18}$ molec $\mathrm{cm}^{-2}$; these values were extrapolated onto the entire plume. Using a simple mass balance model, the total $\mathrm{CO}$ emitted by fires was estimated with and without this correction. Taking into account the missing CO increases the retrieved emission 40-100\% with a final estimate of total $\mathrm{CO}$ emission between 34 and $40 \pm 12 \mathrm{Tg}$.

\section{Appendix A}

\section{Acronyms and abbreviations}

\begin{tabular}{|c|c|}
\hline AIRS & Atmospheric Infrared Sounder \\
\hline AKP & Averaging Kernel for Profile \\
\hline$A K T$ & Averaging Kernel for Total column \\
\hline$A K T N$ & $\begin{array}{l}\text { Averaging Kernel for Total column } \\
\text { Normalized }\end{array}$ \\
\hline ANN & Artificial Neural Network \\
\hline BL & Boindary Layer \\
\hline ECMWF & $\begin{array}{l}\text { European Center for Medium-Range } \\
\text { Weather Forecasts }\end{array}$ \\
\hline EUMETSAT & $\begin{array}{l}\text { European Organization for the Exploita- } \\
\text { tion of Meteorological Satellites }\end{array}$ \\
\hline FORLI-CO & $\begin{array}{l}\text { Fast Optimal Retrievals on Layers for } \\
\text { IASI-CO }\end{array}$ \\
\hline GEOS & Goddard Earth Observing System model \\
\hline GMAO & $\begin{array}{l}\text { Global Modeling and Assimilation } \\
\text { Office }\end{array}$ \\
\hline GSFC & Goddard Space Flight Center \\
\hline IAP & $\begin{array}{l}\text { Obukhov Institute of Atmospheric } \\
\text { Physics }\end{array}$ \\
\hline IASI & $\begin{array}{l}\text { Infrared Atmospheric Sounding } \\
\text { Interferometer }\end{array}$ \\
\hline kCARTA & $\begin{array}{l}\text { kCompressed Atmospheric Radiative } \\
\text { Transfer Algorithm }\end{array}$ \\
\hline MAPS & $\begin{array}{l}\text { Measurements of Atmospheric Pollution } \\
\text { from Satellite }\end{array}$ \\
\hline
\end{tabular}

\begin{tabular}{|c|c|}
\hline $\mathrm{MCO}$ & Missing CO \\
\hline MOPITT & $\begin{array}{l}\text { Measurements Of Pollution In The } \\
\text { Troposphere }\end{array}$ \\
\hline MOZART & $\begin{array}{l}\text { Model for OZone And Related chemical } \\
\text { Tracers }\end{array}$ \\
\hline MSU & Moscow State University \\
\hline NDACC & $\begin{array}{l}\text { Network for Detection of Atmospheric } \\
\text { Composition Change }\end{array}$ \\
\hline NDIR & Non-Dispersive Infrared \\
\hline NH & Northern Hemisphere \\
\hline NIR & Near Infrared \\
\hline OMI & Ozone Monitoring Instrument \\
\hline RTIASI & Radiative Transfer algorithm for IASI \\
\hline SARTA & $\begin{array}{l}\text { Stand-Alone Radiative Transfer } \\
\text { Algorithm }\end{array}$ \\
\hline SCIAMACHY & $\begin{array}{l}\text { SCanning Imaging Absorption } \\
\text { SpectroMeter for Atmospheric } \\
\text { ChartographY }\end{array}$ \\
\hline SF & Scaling Factor \\
\hline SFA & Spectral Fitting Algorithm \\
\hline $\mathrm{SH}$ & Southern Hemisphere \\
\hline $\mathrm{TC}$ & Total Column \\
\hline TES & Tropospheric Emission Spectrometer \\
\hline TIR & Thermal Infrared \\
\hline UTC & Universal Time Coordinated \\
\hline VMR & Volume Mixing Ratio \\
\hline VMR-500 & $\begin{array}{l}\text { Volume Mixing Ratio for the } 500 \mathrm{hPa} \\
\text { atmospheric pressure level }\end{array}$ \\
\hline
\end{tabular}

Acknowledgements. The authors are grateful to Nikolay Elansky (IAP) for the help in using supplemental in situ measurement results. We thank Sergio DeSouza-Machado (UMBC) for the help in a modification of kCARTA model. Merritt Deeter (NCAR, Boulder, USA) clarified issues connected with new versions of MOPITT data. We are grateful to Meinrat Andreae (MPI for Chemistry, Mainz, Germany) and to Bob Yokelson (University of Montana, USA) for a helpful discussion. We thank Daniel Hurtmans (ULB, Belgium) for his help with the IASI FORLI-CO data. This research was supported through a subcontract with the AIRS Project Office at JPL: "Optimization, Validation, and Integrated EOS Analysis". Measurements in Russia have been possible due to funding from RFBR (grant \# 08-05-00659) and ISTC (grant \# 3032). Maya George is grateful to CNES for financial support. We thank the NASA, Centre for Atmospheric Chemistry Products and Services (France), and the EUMETSAT for access to the archived data.

Edited by: M. Kopacz

\section{References}

Aumann, H. H., Chahine, M. T., Gautier, C., Goldberg, M., Kalnay, E., McMillin, L., Revercomb, H., Rosenkranz, P. W., Smith, W. L., Staelin, D. H., Strow, L., and Susskind, J.: AIRS/AMSU/HSB on the Aqua mission: Design, science objectives, data products, and processing systems, IEEE T. Geosci. Remote Sens., 41, 253264, 2003. 
Barret, B., De Mazière, M., and Mahieu, E.: Ground-based FTIR measurements of CO from the Jungfraujoch: characterisation and comparison with in situ surface and MOPITT data, Atmos. Chem. Phys., 3, 2217-2223, doi:10.5194/acp-3-2217-2003, 2003.

Chahine, M. T., Pagano, T. S., Aumann, H. H.,, Atlas, R., Barnet, C., Blaisdell, J., Chen, L., Divakarla, M., Fetzer, E. J., Goldberg, M., Gautier, C., Granger, S., Hannon, S., Irion, F. W., Kakar, R., Kalnay, E., Lambrigtsen, B. H., Lee, S.-Y., Le Marshall, J., McMillan, W. W., McMillin, L., Olsen, E. T., Revercomb, H., Rosenkranz, P., Smith, W. L., Staelin, D., Strow, L. L., Susskind, J., Tobin, D., Wolf, W., and Zhou, L.: The Atmospheric Infrared Sounder (AIRS): Providing new insights into weather and climate for the 21st century, B. Am. Meteorol. Soc., 87, 911-926, 2006.

Chevalier, F.: Sampled Database of 60 Levels Atmospheric Profiles from the ECMWF Analysis, Technical Report, ECMWF EUMETSAT SAF programme Research Report 4; ECMWF, 2001.

Chevallier, F., Fortems, A., Bousquet, P., Pison, I., Szopa, S., Devaux, M., and Hauglustaine, D. A.: African CO emissions between years 2000 and 2006 as estimated from MOPITT observations, Biogeosciences, 6, 103-111, doi:10.5194/bg-6-103-2009, 2009.

Clerbaux, C., George, M., Turquety, S., Walker, K. A., Barret, B., Bernath, P., Boone, C., Borsdorff, T., Cammas, J. P., Catoire, V., Coffey, M., Coheur, P.-F., Deeter, M., De Mazière, M., Drummond, J., Duchatelet, P., Dupuy, E., de Zafra, R., Eddounia, F., Edwards, D. P., Emmons, L., Funke, B., Gille, J., Griffith, D. W. T., Hannigan, J., Hase, F., Höpfner, M., Jones, N., Kagawa, A., Kasai, Y., Kramer, I., Le Flochmoën, E., Livesey, N. J., López-Puertas, M., Luo, M., Mahieu, E., Murtagh, D., Nédélec, P., Pazmino, A., Pumphrey, H., Ricaud, P., Rinsland, C. P., Robert, C., Schneider, M., Senten, C., Stiller, G., Strandberg, A., Strong, K., Sussmann, R., Thouret, V., Urban, J., and Wiacek, A.: CO measurements from the ACE-FTS satellite instrument: data analysis and validation using ground-based, airborne and spaceborne observations, Atmos. Chem. Phys., 8, 2569-2594, doi:10.5194/acp-8-2569-2008, 2008.

Clerbaux, C., Boynard, A., Clarisse, L., George, M., Hadji-Lazaro, J., Herbin, H., Hurtmans, D., Pommier, M., Razavi, A., Turquety, S., Wespes, C., and Coheur, P.-F.: Monitoring of atmospheric composition using the thermal infrared IASI/MetOp sounder, Atmos. Chem. Phys., 9, 6041-6054, doi:10.5194/acp-9-6041-2009, 2009.

Deeter, M. N., Emmons, L. K., Edwards, D. P., Gille, J. C., and Drummond, J. R.: Vertical resolution and information content of CO profiles retrieved by MOPITT, Geophys. Res. Lett., 31, L15112, doi:10.1029/2004GL020235, 2004.

Deeter, M. N., Edwards, D. P., Gille, J. C., and Drummond, J. R.: CO retrievals based on MOPITT nearinfrared observations, J. Geophys. Res.-Atmos., 114, D04303, doi:10.1029/2008JD010872, 2009.

Deeter, M. N., Edwards, D. P., Gille, J. C., Emmons, L. K., Francis, G., Ho, S.-P., Mao, D., Masters, D., Worden, H., Drummond, J. R., and Novelli, P. C.: The MOPITT Version 4 CO Product: Algorithm Enhancements, Validation, and Long-Term Stability, J. Geophys. Res.-Atmos., 115, D07306, doi:10.1029/2009JD013005, 2010.

DeSouza-Machado, S., Strow, L., and Hannon, S.: kCompressed atmospheric radiative transfer algorithm (kCARTA), in Satellite Remote Sensing of Clouds and the Atmosphere, Procs. Of the European Symposium on Aerospace Remote Sensing \#3220, Europto Series, Institute of Electrical Engineers, London, Great Britain, 1997.

Dianov-Klokov, V. I.: Spectroscopic studies of atmospheric pollution over large cities (in Russian). Izvestia AN SSSR, Fizika atmosfery i okeana, 20, 883-900, 1984.

de Laat, A. T. J., Gloudemans, A. M. S., Aben, I., Krol, M., Meirink, J. F., van der Werf, G. R., and Schrijver, H.: Scanning Imaging Absorption Spectrometer for Atmospheric Chartography carbon monoxide total columns: statistical evaluation and comparison with chemistry transport model results, J. Geophys. Res.-Atmos., 112, D21306, doi:10.1029/2007jd009378, 2007.

de Laat, A. T. J., Gloudemans, A. M. S., Aben, I., and Schrijver, H.: Global evaluation of SCIAMACHY and MOPITT carbon monoxide column differences for 2004-2005, J. Geophys. Res.Atmos., 115, D06307, doi:10.1029/2009jd012698, 2010.

Duncan B. N., Logan, J. A., Bey, I., Megretskaia, I. A., Yantosca, R. M., Novelli, P. C., Jones, N. B., and Rinsland, C. P.: Global budget of CO, 1988-1997: Source estimates and validation with a global model, J. Geophys. Res.-Atmos., 112, D22301, doi:10.1029/2007JD008459, 2007.

Drummond, J. R.: Measurements of Pollution in the Troposphere (MOPITT), in: The Use of EOS for Studies of Atmospheric Physics, edited by: Gille, J. C. and Visconti, G., 77-101, NorthHolland, NY, 1992.

Edwards, D. P., Emmons, L. K., Hauglustaine, D. A., Chu, A., Gille, J. C., Kaufman, Y. J., P'etron, G., Yurganov, L. N., Giglio, L., Deeter, M. N., Yudin, V., Ziskin, D. C., Warner, J., Lamarque, J.F., Francis, G. L., Ho, S. P., Mao, D., Chan, J., and Drummond, J. R.: Observations of Carbon Monoxide and Aerosol From the Terra Satellite: Northern Hemisphere Variability, J. Geophys. Res.-Atmos., 109, D24202, doi:10.1029/2004JD004727, 2004.

Edwards, D. P., Emmons, L. K., Gille, J. C., Chu, A., Atti'e, J.-L., Giglio, L., Wood, S. W., Haywood, J., Deeter, M. N., Massie, S. T., Ziskin, D. C., and Drummond J. R.: Satellite-observed pollution from Southern Hemisphere biomass burning, J. Geophys. Res.-Atmos., 111, D14312, doi:10.1029/2005JD006655, 2006.

Emmons, L. K., Deeter, M. N., Gille, J. C., Edwards, D. P., Atti'e, J.-L., Warner, J., Ziskin, D., Francis, G., Khattatov, B., Yudin,V., Lamarque, J.-F., Ho, S.-P., Mao, D., Chen, J. S., Drummond,J., Novelli, P., Sachse, G., Coffey, M. T., Hannigan, J. W.,Gerbig, C., Kawakami, S., Kondo, Y., Takegawa, N., Schlager,H., Baehr, J., and Ziereis, H.: Validation of Measurements of Pollution in the Troposphere (MOPITT) CO retrievals with aircraft in situ profiles, J. Geophys. Res.-Atmos., 109, D03309, doi:10.1029/2003JD004101, 2004.

Emmons, L. K., Pfister, G. G., Edwards, D. P., Gille, J. C., Sachse, G., Blake, D. Wofsy, S., Gerbig, C., Matross, D., and Nédélec, P.: Measurements of Pollution in the Troposphere (MOPITT): validation exercises during summer 2004 field campaigns over North America, J. Geophys. Res.-Atmos., 112, D12S02, doi:10.1029/2006JD007833, 2007.

Emmons, L. K., Edwards, D. P., Deeter, M. N., Gille, J. C., Campos, T., Nédélec, P., Novelli, P., and Sachse, G.: Measurements of Pollution In The Troposphere (MOPITT) validation through 2006, Atmos. Chem. Phys., 9, 1795-1803, doi:10.5194/acp-91795-2009, 2009. 
Fisher, J. A., Jacob, D. J., Purdy, M. T., Kopacz, M., Le Sager, P., Carouge, C., Holmes, C. D., Yantosca, R. M., Batchelor, R. L., Strong, K., Diskin, G. S., Fuelberg, H. E., Holloway, J. S., Hyer, E. J., McMillan, W. W., Warner, J., Streets, D. G., Zhang, Q., Wang, Y., and Wu, S.: Source attribution and interannual variability of Arctic pollution in spring constrained by aircraft (ARCTAS, ARCPAC) and satellite (AIRS) observations of carbon monoxide, Atmos. Chem. Phys., 10, 977-996, doi:10.5194/acp-10-977-2010, 2010.

Fokeeva, E. V., Safronov, A.N., Rakitin, V. S., Yurganov, L. N., Grechko, E. I., and Shumski, R. A.: Influence of wildfires in July-August 2010 on carbon monoxide atmospheric pollution in Moscow and environs, emission estimates. Izvestiya, Atmos. Ocean. Phys., in press, 2011.

George, M., Clerbaux, C., Hurtmans, D., Turquety, S., Coheur, P.F., Pommier, M., Hadji-Lazaro, J., Edwards, D. P., Worden, H., Luo, M., Rinsland, C., and McMillan, W.: Carbon monoxide distributions from the IASI/METOP mission: evaluation with other space-borne remote sensors, Atmos. Chem. Phys., 9, 8317-8330, doi:10.5194/acp-9-8317-2009, 2009.

Gloudemans, A. M. S., Schrijver, H., Hasekamp, O. P., and Aben, I.: Error analysis for $\mathrm{CO}$ and $\mathrm{CH}_{4}$ total column retrievals from SCIAMACHY $2.3 \mu \mathrm{m}$ spectra, Atmos. Chem. Phys., 8, 39994017, doi:10.5194/acp-8-3999-2008, 2008.

Haskins, R. and Kaplan, L.: Remote sensing of trace gases using the Atmospheric InfraRed Sounder, in: IRS'92: Current Problems in Atmospheric Radiation: Proceedings of the International Radiation Symposium, Tallinn, Estonia, 3-8 August 1992, edited by: Keevallik, S. and Karner, O., 278-281, A. Deepak, Hampton, Va., 1992.

Holloway, T., Levy, H., and Kasibhatla, P.: Global distribution of carbon monoxide, J. Geophys. Res., 105(D10), 12123-12147, 2000.

Hébert, Ph., Blumstein, D., Buil, C., Carlier, T., Chalon, G., Astruc, P., Clauss, A., Siméoni, D., and Tournier, B.: IASI instrument: technical description and measured performances, in: Proceedings of the 5th International Conference on Space Optics (ICSO 2004), 30 March-2 April 2004, Toulouse, France, edited by: Warmbein, B., ESA SP-554, Noordwijk, The Netherlands, ESA Publications Division, ISBN 92-9092-865-4, 49-56, 2004.

Konovalov, I. B., Beekmann, M., Kuznetsova, I. N., Yurova, A., and Zvyagintsev, A. M.: Atmospheric impacts of the 2010 Russian wildfires: integrating modelling and measurements of the extreme air pollution episode in the Moscow megacity region, Atmos. Chem. Phys. Discuss., 11, 12141-12205, doi:10.5194/acpd-11-12141-2011, 2011.

Kopacz, M., Jacob, D. J., Fisher, J. A., Logan, J. A., Zhang, L., Megretskaia, I. A., Yantosca, R. M., Singh, K., Henze, D. K., Burrows, J. P., Buchwitz, M., Khlystova, I., McMillan, W. W., Gille, J. C., Edwards, D. P., Eldering, A., Thouret, V., and Nedelec, P.: Global estimates of CO sources with high resolution by adjoint inversion of multiple satellite datasets (MOPITT, AIRS, SCIAMACHY, TES), Atmos. Chem. Phys., 10, 855-876, doi:10.5194/acp-10-855-2010, 2010.

Liu, C., Beirle, S., Butler, T., Liu, J., Hoor, P., Jöckel, P., Pozzer, A., Frankenberg, C., Lawrence, M. G., Lelieveld, J., Platt, U., and Wagner, T.: Application of SCIAMACHY and MOPITT CO total column measurements to evaluate model results over biomass burning regions and Eastern China, Atmos. Chem. Phys., 11,
6083-6114, doi:10.5194/acp-11-6083-2011, 2011.

Logan, J. A., Prather, M. J., Wofsy, S. C., and McElroy, M. B.: Tropospheric chemistry: A global perspective, J. Geophys. Res.Atmos., 86, 7210-7354, 1981.

Malkov, I. P., Yurganov, L. N., Dianov-Klokov, V.I.: Measurements of $\mathrm{CO}$ and $\mathrm{CH}_{4}$ contents in the Northern and Southern hemispheres (preliminary results), Izv. Acad. Sci. USSR, Atmos. Oceanic Phys., Engl. Transl., 12, 754-757, 1976.

McKernan, E., Yurganov, L. N., Tolton, B. T., and Drummond, J. R.: MOPITT validation using ground-based IR spectroscopy, Proc. SPIE, 3756, 486-491, 1999.

McMillan, W. W., Barnet, C., Strow, L., Chahine, M. T., McCourt, M. L., Warner, J. X., Novelli, P. C., Korontzi, S., Maddy, E. S., and Datta, S.: Daily global maps of carbon monoxide from NASA's Atmospheric Infrared Sounder, Geophys. Res. Lett., 32, L11801, doi:10.1029/2004GL021821, 2005.

McMillan, W. W., Warner, J. X., McCourt-Comer, M., Maddy, E., Chu, A., Sparling, L., Eloranta, E., Hoff, R., Sachse, G., Barnet, C., Razenkov, I., and Wolf, W.: AIRS views transport from 12 to 22 July 2004 Alaskan/Canadian fires: Correlation of AIRS CO and MODIS AOD with forward trajectories and comparison of AIRS CO retrievals with DC-8 in situ measurements during INTEX-A/ICARTT, J. Geophys. Res.-Atmos., 113, D20301, doi:10.1029/2007JD009711, 2008.

McMillan, W. W., Pierce, R., Sparling, L. C., Osterman, G., McCann, K., Fischer, M. L., Rappenglueck, B., Newton, R., Turner, D. D., Kittaka, C., Evans, K., Biraud, S., Lefer, B., Andrews, A., and Oltmans, S.:An Observational and modeling strategy to investigate the impact of remote sources on local air quality: A Houston, Texas case study from TEXAQS II, J. Geophys. Res.Atmos., 115, D01301, doi:10.1029/2009JD011973, 2010.

McMillan, W. W., Evans, K., Barnet, C., Maddy, E., Sachse, G., and Diskin, G.: Validating the AIRS Version $5 \mathrm{CO}$ Retrieval with DACOM in situ Measurements During INTEXA and-B, IEEE T. Geosci. Remote Sens., 49, 2802-2813, doi:10.1109/TGRS.2011.2106505, 2011.

Pfister, G., Hess, P. G., Emmons, L. K., Lamarque, J.F.,Wiedimeyer, C., Edwards, C. P., Petron, G., Gille, J. C., and Sachse, G. W.: Quantifying co emissions from the 2004 Alaskan wildfires using MOPITT-CO data, Geophys. Res. Lett., 32, L11809, doi:11810.11029/12005GL022995, 2005.

Pommier, M., Law, K. S., Clerbaux, C., Turquety, S., Hurtmans, D., Hadji-Lazaro, J., Coheur, P.-F., Schlager, H., Ancellet, G., Paris, J.-D., Nédélec, P., Diskin, G. S., Podolske, J. R., Holloway, J. S., and Bernath, P.: IASI carbon monoxide validation over the Arctic during POLARCAT spring and summer campaigns, Atmos. Chem. Phys., 10, 10655-10678, doi:10.5194/acp-1010655-2010, 2010.

Potter, B. E.: A dynamics based view of atmosphere-fire interactions, International Journal of Wildland Fire, 11, 247-255, 2002.

Rakitin, V. S., Fokeeva, E. V., Grechko, E. I., Dzhola, A. V., and Kuznetsov, R. D.: Variations of the Total Content of Carbon Monoxide over Moscow Megapolis, Izvestiya, Atmos. Ocean. Phys., 47(1), 59-66, 2011.

Reichle, H. G., Connors, V. S., Holland, J. A., Hypes, W. D., Wallio, H. A., Casas, J. C., Gormsen, B. B., Saylor, M. S., and Hesketh, W. D.: Middle and upper tropospheric carbon monoxide mixing ratios as measured by a satellite-borne remote sensor during November 1981, J. Geophys. Res.-Atmos., 91, 10865-10887, 
1986.

Rodgers, C. D.: Inverse methods for atmospheric sounding: theory and practice, Ser. Atmos. Ocean. Planet. Phys. 2, World Sci., Hackensack, NJ, 2000.

Roy, D. P., Boschetti, L., Justice, C. O.: The Collection 5 MODIS Burned Area Product - Global Evaluation by Comparison with the MODIS Active Fire Product, Remote Sens. Environ., 112, 3690-3707, doi:10.1016/j.rse.2008.05.013, 2008.

Schlüssel, P., Hultberg, T. H., Phillips, P. L., August, T., and Calbet, X.: The operational IASI Level 2 processor, Adv. Space Res., 36, 982-988, 2005.

Spivakovsky, C. M., Logan, J. A., Montzka, S. A., Balkanski, Y. J., Foreman-Fowler, M., Jones, D. B. A., Horowitz, L. A., Fusco, A. C., Brenninkmeijer, C. A. M., Prather, M. J., Wofsy, S. C., and McElroy, M. B.: Three-dimensional climatological distribution of tropospheric $\mathrm{OH}$ : Update and evaluation, J. Geophys. Res., 105, 8931-8980, 2000.

Strow, L. L. and Hannon, S. E.: A 4-year zonal climatology of lower tropospheric $\mathrm{CO}_{2}$ derived from ocean-only Atmospheric Infrared Sounder observations, J. Geophys. Res., 113, D18302, doi:10.1029/2007JD009713, 2008.

Strow, L. L., Hannon S. E., de Souza-Machado, S., Motteler, H. E., and Tobin, D.: An overview of the AIRS radiative transfer model, IEEE T. Geosci. Remote Sens., 41, 303-313, doi:10.1109/TGRS.2002.808244, 2003.

Strow, L. L., Hannon, S. E., De-Souza Machado, S., Motteler, H. E., and Tobin, D. C.: Validation of the Atmospheric Infrared Sounder radiative transfer algorithm, J. Geophys. Res., 111, D09S06, doi:10.1029/2005JD006146, 2006.

Susskind, J., Barnet, C. D., and Blaisdell, J. M.: Retrieval of atmospheric and surface parameters from AIRS/AMSU/HSB data in the presence of clouds, IEEE T. Geosci. Remote Sens., 41, 390-409, 2003.

Torres O., Bhartia, P. K., Herman, J. R., and Ahmad, Z.: Derivation of aerosol properties from satellite measurements of backscattered ultraviolet radiation. Theoretical Basis, J. Geophys. Res.Atmos., 103, 17099-17110, 1998.

Turquety, S., Clerbaux, C., Law, K., Coheur, P.-F., Cozic, A., Szopa, S., Hauglustaine, D. A., Hadji-Lazaro, J., Gloudemans, A. M. S., Schrijver, H., Boone, C. D., Bernath, P. F., and Edwards, D. P.: $\mathrm{CO}$ emission and export from Asia: an analysis combining complementary satellite measurements (MOPITT, SCIAMACHY and ACE-FTS) with global modeling, Atmos. Chem. Phys., 8, 5187-5204, doi:10.5194/acp-8-5187-2008, 2008.

Turquety, S., Hurtmans, D., Hadji-Lazaro, J., Coheur, P.-F., Clerbaux, C., Josset, D., and Tsamalis, C.: Tracking the emission and transport of pollution from wildfires using the IASI CO retrievals: analysis of the summer 2007 Greek fires, Atmos. Chem. Phys., 9, 4897-4913, doi:10.5194/acp-9-4897-2009, 2009.

van der Werf, G. R., Randerson, J. T., Giglio, L., Collatz, G. J., Mu, M., Kasibhatla, P. S., Morton, D. C., DeFries, R. S., Jin, Y., and van Leeuwen, T. T.: Global fire emissions and the contribution of deforestation, savanna, forest, agricultural, and peat fires (19972009), Atmos. Chem. Phys., 10, 11707-11735, doi:10.5194/acp10-11707-2010, 2010.

Wan, Z.: New refinements and validation of the MODIS land surface temperature/emissivity products, Remote Sens. Environ., 112, 59-74, 2008.

Warner, J. M. M. C., Barnet, C. D., McMillan, W. W., Wolf,
W., Maddy, E., and Sachse, G.: comparison of satellite tropospheric carbon monoxide measurements from AIRS and MOPITT during INTEX-A, J. Geophys. Res.-Atmos., 112, D12S17, doi:10.1029/2006JD007925, 2007.

Wendler, G., Conner, J., Moore, B., Shulski, M., and Stuefer, M.: Climatology of Alaskan wildfires with special emphasis on the extreme year of 2004, Theor. Appl. Climatol., 104(3-4), 459472, doi:10.1007/s00704-010-0357-9, 2010.

Wiedinmyer, Ch., Quayle, B., Geron, Ch., Belote, A., McKenzie, D., Zhang, X., O’Neill, S., and Wynne, K.: Estimating emissions from fires in North America for air quality modeling, Atmos. Environ., 40, 3419-3432, doi:10.1016/j.atmosenv.2006.02.010, 2006.

Witte, J. C., Douglass, A. R., da Silva, A., Torres, O., Levy, R. C., and Duncan, B. N.: NASA A-Train and Terra observations of the 2010 Russian wildfires, Atmos. Chem. Phys. Discuss., 11, 19113-19142, doi:10.5194/acpd-11-19113-2011, 2011.

Worden, H. M., Deeter, M. N., Edwards, D. P., Gille, J. C., Drummond, J. R., and Nédélec, P.: Observations of near-surface carbon monoxide from space using MOPITT multispectral retrievals, J. Geophys. Res., 115, D18314, doi:10.1029/2010JD014242, 2010.

Yurganov, L. N., Grechko, E. I., and Dzhola, A. V.: Long-term measurements of carbon monoxide over Russia using a spectrometer of medium resolution, Recent Res. Devel. Geophysics, 4, 249265, ISBN 81-7736-076-0, 2002.

Yurganov, L. N., Blumenstock, T., Grechko, E. I., Hase, F., Hyer, E. J., Kasischke, E. S., Koike, M., Kondo, Y., Kramer, I., Leung, F.-Y., Mahieu, E., Mellqvist, J., Notholt, J., Novelli, P. C., Rinsland, C. P., Scheel, H.-E., Schulz, A., Strandberg, A., Sussmann, R., Tanimoto, H., Velazco, V., Zander, R., and Zhao, Y.: A quantitative assessment of the 1998 carbon monoxide emission anomaly in the northern hemisphere based on total column and surface concentration measurements, J. Geophys. Res., 109, D15305, doi:10.1029/2004JD004559, 2004.

Yurganov, L. N., Duchatelet, P., Dzhola, A. V., Edwards, D. P., Hase, F., Kramer, I., Mahieu, E., Mellqvist, J., Notholt, J., Novelli, P. C., Rockmann, A., Scheel, H. E., Schneider, M., Schulz, A., Strandberg, A., Sussmann, R., Tanimoto, H., Velazco, V., Drummond, J. R., and Gille, J. C.: Increased Northern Hemispheric carbon monoxide burden in the troposphere in 2002 and 2003 detected from the ground and from space, Atmos. Chem. Phys., 5, 563-573, doi:10.5194/acp-5-563-2005, 2005.

Yurganov, L., McMillan, W., Dzhola, A., Grechko, E, Jones N., and van der Werf, G.: Global AIRS and MOPITT CO Measurements: Validation, Comparison, and Links to Biomass Burning Variations and Carbon Cycle, J. Geophys. Res.-Atmos., 113, D09301, doi:10.1029/2007JD009229, 2008.

Yurganov, L., McMillan, W., Grechko, E., and Dzhola, A.: Analysis of global and regional $\mathrm{CO}$ burdens measured from space between 2000 and 2009 and validated by ground-based solar tracking spectrometers, Atmos. Chem. Phys., 10, 3479-3494, doi:10.5194/acp-10-3479-2010, 2010.

Zhou, D. K., Larar, A. M., Liu, X., Smith, W. L., Strow, L. L., Yang, P., Schlüssel, P., and Calbet, X.: Global land surface emissivity retrieved from satellite ultraspectral IR measurements, IEEE T. Geosci. Remote Sens., 49(4), 1277-1290, doi:10.1109/TGRS.2010.2051036, 2011. 